\title{
The roles of beta-adrenergic receptors in tumorigenesis and the possible use of beta-adrenergic blockers for cancer treatment: possible genetic and cell-signaling mechanisms
}

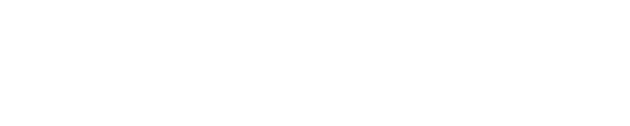

Khanh vinh quốc Lương Lan Thi Hoàng Nguyễn

Vietnamese American Medical Research Foundation, Westminster. California, USA
Correspondence: Khanh vinh quôc Lương I497I Brookhurst St, Westminster, CA 92683, USA

$\mathrm{Tel}+\mathrm{I} 7148395898$

Fax + I 7|48395989

Email Ing2687765@aol.com

\begin{abstract}
Cancer is the leading cause of death in the USA, and the incidence of cancer increases dramatically with age. Beta-adrenergic blockers appear to have a beneficial clinical effect in cancer patients. In this paper, we review the evidence of an association between $\beta$-adrenergic blockade and cancer. Genetic studies have provided the opportunity to determine which proteins link $\beta$-adrenergic blockade to cancer pathology. In particular, this link involves the major histocompatibility complex class II molecules, the renin-angiotensin system, transcription factor nuclear factor-kappa-light-chain-enhancer of activated B cells, poly(ADP-ribose) polymerase-1, vascular endothelial growth factor, and the reduced form of nicotinamide adenine dinucleotide phosphate oxidase. Beta-adrenergic blockers also exert anticancer effects through non-genomic factors, including matrix metalloproteinase, mitogen-activated protein kinase pathways, prostaglandins, cyclooxygenase-2, oxidative stress, and nitric oxide synthase. In conclusion, $\beta$-adrenergic blockade may play a beneficial role in cancer treatment. Additional investigations that examine $\beta$-adrenergic blockers as cancer therapeutics are required to further elucidate this role.
\end{abstract}

Keywords: $\beta$-adrenergic blocker, neoplasm, $\beta$-adrenergic antagonism, non-genomic factor

\section{Introduction}

The relationship between $\beta$-adrenergic antagonism and cancer has been well established in the literature. The function of $\beta$-adrenergic receptors was demonstrated in the cell membranes of breast cancer cells by the significant increase in cyclic adenosine monophosphate (cAMP) production induced by different concentrations of isoproterenol compared with cells that were unstimulated (control). ${ }^{1}$ Further, $\beta$-adrenergic receptors were implicated in the regulation of cell growth in lung cancer cell lines via the cAMP signaling pathway. ${ }^{2,3}$ Beta-adrenergic receptors were more highly expressed in oral squamous-cell carcinomas than in normal controls cells, and their expression was correlated with cervical lymph node metastasis, age, tumor size, and clinical stage. ${ }^{4}$ The $\beta_{2}$-adrenergic receptor density in hepatocellular carcinoma (HCC) cellular membranes was higher than the $\beta_{2}$-adrenergic receptor density in nonadjacent non-tumor liver cell membranes. ${ }^{5}$ Isoproterenol significantly increased cell proliferation via $\beta$-adrenergic receptors in a dose-dependent manner, with the concomitant activation of the extracellular signal-regulated kinase (ERK)/mitogen-activated protein kinase (MAPK) signaling pathway in pancreatic cancer cells. ${ }^{6}$ In several experimental cancer models, the activation of the sympathetic nervous system promotes the metastasis of solid epithelial 
tumors and the dissemination of hematopoietic malignancies via the $\beta$-adrenoreceptor-mediated activation of protein kinase A (PKA) and the activation of exchange proteins by the adenylate cyclase signaling pathways. Interestingly, common haplotypes of the $\beta_{2}$-adrenergic receptor, which affect its translational efficiency, are associated with longevity in men and the level of $\beta_{2}$-adrenergic receptor protein is inversely associated with male lifespan. ${ }^{7}$ These findings may well have clinical implications for treating patients with $\beta$-adrenergic receptor agonists or antagonists.

Beta-blockers, used in a clinical context, reduced the rates of progression of several solid tumors. ${ }^{8}$ Chronic stress can accelerate the progression of human acute lymphoblastic leukemia via $\beta$-adrenergic signaling. ${ }^{9}$ Psychological stress promotes the progression of pancreatic cancer xenografts via neurotransmitter-induced activation of multiple pathways and increases systemic and tumor levels of norepinephrine (NE), epinephrine, cortisol, vascular endothelial growth factor (VEGF), and cAMP. ${ }^{10}$ Social stress also stimulates non-small cell lung carcinoma (NSCLC) by increasing nicotinic acetylcholine receptor-mediated stress neurotransmitter signaling. ${ }^{11}$ These findings are consistent with sympathetic effects on cell growth in cancer.

Epinephrine significantly increased the esophageal squamous-cell carcinoma cell proliferation that accompanied the elevation of intracellular cAMP levels, which were decreased by $\beta$-adrenergic antagonists. ${ }^{12}$ The development of lumbar lymph node metastases of human prostate cancer cells in athymic BALB/c nude mice increased with the application of NE via micro-osmotic pumps, and propranolol inhibited this effect. ${ }^{13}$ Exposure to nicotine either by tobacco smoke or nicotine supplements facilitates the growth and progression of NSCLC, and pharmacological intervention with $\beta$-blockers may lower the risk of NSCLC development among smokers. ${ }^{14}$ In elderly malnourished cancer patients, atenolol and propranolol treatment reduced resting energy expenditure, ${ }^{15}$ and propranolol decreased patient's basal metabolic rates. ${ }^{16}$ Beta-blockers have also been associated with reduced prostate cancer-specific mortality, a 54\% reduction in epithelial ovarian cancer death, a reduced risk in progression of thick malignant melanoma, the inhibition of astrocytoma cell proliferation, the induction of human gastric cancer cell apoptosis, the stimulation of cell cycle arrest, and the prevention of pancreatic cancer. ${ }^{17-22}$ In breast cancer, $\beta$-blocker use improved relapse-free survival in all patients with breast cancer; this effect was particular pronounced in patients with triple-negative breast cancer. The use of $\beta$-blockers resulted in a $57 \%$ reduction in the risk of metastasis and a
$71 \%$ reduction in the 10 -year mortality rate, and $\beta$-blockers could potentially be administered concomitantly with chemotherapy to increase treatment efficacy in breast cancer patients. ${ }^{23-26}$ Following $\beta$-adrenergic-receptor stimulation, receptor activator of nuclear factor kappa-B ligand (RANKL) expression was induced in bone marrow osteoblasts and increased the migration of metastatic breast cancer MDA231 cells in vitro. Further, RANKL expression can be blocked with the $\beta$-blocker propranolol in MDA-231 cells. Beta-blockers and drugs that interfere with RANKL signaling, such as denosumab, could increase patient survival if used as an adjuvant therapy to inhibit the early colonization of bone by metastatic breast cancer cells. ${ }^{27}$ In a retrospective study, propranolol treatment decreased the incidence of HCC in patients with compensated hepatitis $\mathrm{C}$ virus cirrhosis. ${ }^{28}$ Carvedilol was a very potent inhibitor of cell proliferation in cells derived from breast tumors (MDA-MB-361), melanoma (Fem-x), cervix adenocarcinomas (HeLa) and human myelogenous leukemia. ${ }^{29}$ In addition, ICI 118551, a $\beta_{2}$-adrenoceptor blocker, significantly synergized the antiproliferative and pro-apoptotic effects induced by gemcitabine to inhibit the proliferation of pancreatic cancer cells. ${ }^{30}$ The use of propranolol as an adjunctive treatment has been reported for severe recurrent respiratory papillomatosis. ${ }^{31}$ Propranolol enhanced the sensitivity of gastric cancer cells to radiation by inhibiting $\beta$-adrenergic receptors and the downstream

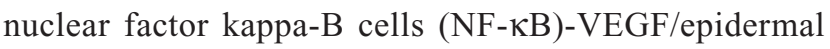
growth factor receptor/cyclooxygenase (COX)-2 pathway. ${ }^{32}$ Propranolol also had antiproliferative and apoptotic effects on multiple myeloma cells. ${ }^{33}$ These findings suggest that $\beta$-adrenergic blockade might play a role in cancer treatment.

Based on the evidence described above, in this review, we discuss the role of $\beta$-adrenergic blockers in cancer.

Figure 1 illustrates the signaling pathways and their connections to $\beta$-adrenergic receptors.

\section{Genetic factors that relate to $\beta$-adrenergic inhibition and cancer}

The major histocompatibility complex (MHC) class II molecules play an important role in the immune system and are essential in the defense against infection. The human MHC class II molecules are encoded by three different human leukocytic antigen (HLA) isotypes: HLA-DR, HLA-DQ, and HLA-DP. Published studies have suggested that several genes within the MHC region promote cancer susceptibility. A chimeric DR4 homozygous transgenic mouse line was reported to spontaneously develop diverse hematological 

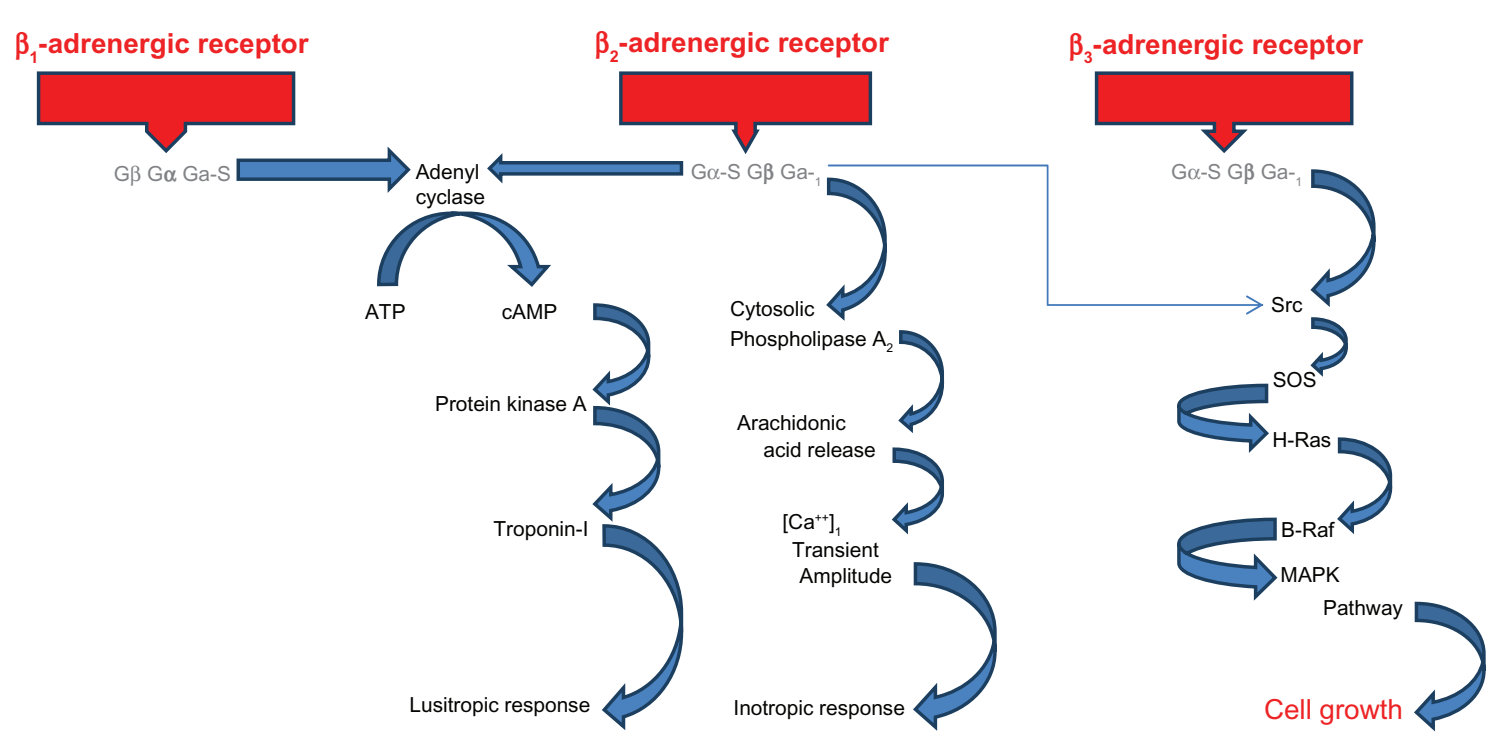

Figure I Signaling pathways and their connections to $\beta$-adrenergic receptors. Abbreviations: ATP, adenosine triphosphate; cAMP, cyclic adenosine monophosphate; MAPK, mitogen-activated protein kinase; SOS, factor Son of Sevenless.

malignancies at a high frequency. ${ }^{34}$ Most of these neoplasms were highly similar to the types of neoplasms that are found in human diseases. HLA-DR antigen expression was correlated with histopathological type and with the degree of cell differentiation in cutaneous squamous-cell carcinomas. ${ }^{35}$ In southern Tunisia, the $D R B 1 * 03$ and $D R-B 1 * 13$ alleles were significantly more frequent in patients with nasopharyngeal carcinoma (NPC). ${ }^{36}$ The $D R l$ gene was shown to be strongly associated with thyroid carcinoma. ${ }^{37}$ HLA-DR was also increased in poorly differentiated thyroid carcinoma and in the anaplastic type of this carcinoma in particular. ${ }^{38}$ In Chinese populations, the $D Q A 1 * 0102$ and $D P B 1 * 0501$ alleles have been reported to be significantly more common in patients with $\mathrm{HCC}$ than in controls. ${ }^{39}$ Among Korean study populations, the frequency of the $D R B 1 * 0404$ allele was significantly higher in gastric cancer patients than in gastritis patients. ${ }^{40}$ However, the frequencies of the DRB $1 * 0405$ and $D Q B 1^{*} 0401$ alleles were increased in Japanese patients with intestinal-type gastric cancer compared with controls. ${ }^{41}$ Somatic mutations affecting HLA class II genes may lead to a loss of HLA class II expression due to the formation of microsatellites in unstable colorectal carcinomas (CRCs). ${ }^{42}$ The $D R B 1 * 15$ allele and the $D R B 1 * 15 D Q B 1 * 0602$ haplotype have been associated with human papillomavirus-16 positive invasive cervical cancer in Mexican women. ${ }^{43}$ It has been demonstrated that the DRB ${ }^{*} 0410$ allele is the susceptibility allele in Japanese patients with testicular germ cell carcinoma. ${ }^{44}$ Furthermore, the frequencies of the $D R B 1 * 09$ and $D Q B 1 * 03$ alleles were increased in patients with non-Hodgkin's lymphoma and diffuse large B-cell lymphoma compared with normal controls. ${ }^{45}$ In a study of Turkish children, the frequencies of the $D R B 1 * 04$ and $D R B 1 * 15$ alleles were significantly higher in patients with acute leukemia than in controls. ${ }^{46}$ In Eastern Canada, the $D R B 1 * 16$ allele was a marker for a significant risk of chronic myelogenous leukemia. ${ }^{47}$ The DRB $1 * 04$ and DRB5 alleles were associated with disease progression in Iranian patients with chronic lymphocytic leukemia. ${ }^{48}$ Moreover, cardiac $\beta$-adrenergic receptors and adenylate cyclase activity in dilated cardiomyopathy were shown to be modulated by circulating autoantibodies against the cardiac $\beta_{1}$-adrenoceptor; the presence of these autoantibodies is controlled by the HLA-DR.$^{49}$ Furthermore, propranolol-abrogated interferongamma increased HLA class II expression and interleukin-1beta (IL-1 $\beta$ ) secretion. ${ }^{50}$ HLA-DR was significantly reduced in the lymphocytes of carvedilol-treated chronic heart failure patients. ${ }^{51}$ These findings suggest that $\beta$-adrenergic blockers may have an effect on cancer by suppressing the expression of MHC class II antigens.

The primary function of the renin-angiotensin system (RAS) is to maintain fluid homeostasis and regulate blood pressure. The angiotensin-converting enzyme (ACE) is a key enzyme in the RAS that converts angiotensin (AT) I to the potent vasoconstrictor AT II. ${ }^{52}$ The local RAS may influence tissue angiogenesis, cellular proliferation, apoptosis, and inflammation. ${ }^{53}$ Epidemiological and experimental studies have suggested that the RAS might contribute to the paracrine regulation of tumor growth. Renin levels are elevated in patients with liver cirrhosis and HCC and have been positively correlated with $\alpha$-fetoprotein. ${ }^{54}$ The overexpression 
of ACE has been reported in extra-hepatic cholangio-carcinoma,${ }^{55}$ leukemic myeloid blast cells, ${ }^{56}$ and macrophages in the lymph nodes of Hodgkin's disease patients..$^{57}$ AT II receptors were also shown to be expressed in all human gastric cancer lines,${ }^{58}$ premalignant and malignant prostate cells, ${ }^{59}$ human lung cancer xenografts, ${ }^{60}$ and ovarian cancer. ${ }^{61}$ The RAS mutation in codon 61 was the most common genetic alteration in poorly differentiated thyroid carcinomas. ${ }^{62}$ The ACE $I / D$ polymorphism has been identified as a possible target for developing genetic markers for breast cancer in Brazilian women. ${ }^{63}$ The ACE $I / D$ polymorphisms were shown to play an important role in breast cancer risk and disease-free survival in Caucasian postmenopausal women. ${ }^{64}$ Carriers of the high-activity $D D$ genotype exhibited an increased risk of breast cancer compared with low activity II/ID genotype carriers. ${ }^{65}$ The $D D$ genotype was associated with patients with an aggressive stage of prostate cancer. ${ }^{66}$ ACE2 expression was decreased in NSCLC and in pancreatic ductal adenocarcinoma, in which AT II levels were higher than in controls. ${ }^{67,68} \mathrm{ACE} 2$ has been suggested as a potential molecular target for pancreatic cancer therapy. ${ }^{69}$ The AT II concentration was significantly higher in the gastric cancer region than in adjacent tissue. ${ }^{70}$ Furthermore, angiotensin II-receptor blockers suppressed the cell proliferation effects of AT II in breast cancer cells. ${ }^{71}$ The addition of ACE inhibitors or angiotensin II-receptor blockers to platinum-based first-line chemotherapy contributed to prolonged survival in patients with advanced lung cancer ${ }^{72}$ and positively affected the prognosis of advanced pancreatic cancer patients receiving gemcitabine. ${ }^{73}$ RAS inhibitors also improved the outcome of sunitinib treatment in metastatic renal cell carcinoma. ${ }^{74}$ Moreover, catecholamines can alter the release of AT II. Ming et $\mathrm{al}^{75}$ demonstrated that isoproterenol enhances the stimulatory effect of dexamethasone on the expression of the $A T$ gene via $\beta_{2}$-adrenergic receptors in mouse hepatoma cells. Isoproterenol promoted an increase in the release of AT II from isolated perfused mesenteric arteries, and this release was blocked by propranolol. ${ }^{76}$ In other studies, isoproterenol also increased the secretion of AT II in neuronal cultures, cultured bovine aortic endothelial cells, and the brachial arteries of hypertensive subjects. ${ }^{77-79}$ Propranolol treatment reduced plasma renin activity, AT I, AT II, and $\mathrm{AT}_{1-7}$ in the portal vein and periphery in cirrhotic patients compared with non-treated patients. ${ }^{80}$ Carvedilol inhibited basal and stimulated ACE production in human endothelial cells ${ }^{81}$ and exhibited beneficial effects on ACE activity and plasma renin activity levels in chronic heart failure patients. ${ }^{82}$ In addition, proliferating infantile hemangioma expressed two essential components of the RAS, namely ACE and the AT II receptor, that accounted for the propranolol-induced accelerated involution of large proliferating infantile hemangioma. ${ }^{83-85}$ Thus, taken together, these findings suggest that the RAS is activated in cancer patients and $\beta$-adrenergic blockers may play a role in cancer by modulating the RAS.

The transcription factor NF- $\mathrm{KB}$ is a hetero-dimeric, sequence-specific transcription factor that is expressed in many cell types. NF- $\mathrm{\kappa B}$ has been implicated in chronic inflammatory diseases and is a key regulator of genes that are involved in responses to infection, inflammation, and stress. The NF- $\mathrm{KB}$ family of transcription factors plays a crucial role in inflammation as well as in the development and progression of cancer. The NF- $\mathrm{KB}$ pathway is dysregulated in prostate cancer and has been implicated in the progression to the androgen-independent state that ultimately leads to patient death. ${ }^{86} \mathrm{NF}-\kappa \mathrm{B}$ activity has been correlated with the progression and prognosis of pancreatic cancer in a mouse model. ${ }^{87}$ $\mathrm{NF}-\kappa \mathrm{B}$ expression was higher in renal cancer specimens than in a control group, ${ }^{88}$ and NF- $\mathrm{KB}$ is known to play an important role in endometrial cancer pathogenesis. ${ }^{89} \mathrm{NF}-\mathrm{\kappa B}$ signaling is important for medulloblastoma tumor growth, and the inhibition of NF- $\mathrm{kB}$ reduced tumor size and viability in vivo. ${ }^{90} \mathrm{It}$ has been reported that the association of the RE-1-silencing transcription factor with NF- $\mathrm{NB}$ increases risks of $\mathrm{CRC}$, colon cancer, and rectal cancer. ${ }^{91} N F-\kappa B$ alleles are associated with oral carcinogenesis. ${ }^{92} \mathrm{NF}-\kappa \mathrm{B}_{1}$ and NF- $\mathrm{KBIA}$ polymorphisms are associated with an increased risk for sporadic colorectal cancer in a southern Chinese population. ${ }^{93} \mathrm{~A}$ homozygous $N F \kappa B \alpha$ rs 17103265 deletion is a novel genetic risk factor for gastric carcinogenesis, particularly for the development of certain subtypes of gastric cancer in a southern Chinese population. ${ }^{94} N F-\kappa B_{1}$ insertion/deletion promoter polymorphism increases the risk of advanced ovarian cancer in Chinese populations..$^{95}$ The functional $N F-\kappa B_{1}-94$ insertion/ deletion ATTG (adenine-thymidine-thymidine-guanine) polymorphism was associated with cervical squamous-cell carcinoma, particularly in individuals who were 35 years of age or younger. ${ }^{96} \mathrm{~A}$ meta-analysis revealed that a common insertion/deletion $\left(N F-\kappa B_{1}-94\right.$ insertion/deletion ATTG, rs28362491) polymorphism in the $N F-\kappa B_{1}$ gene might be associated with a decreased cancer risk, especially in Asian populations.${ }^{97}$ Moreover, cardiac collagen volume fraction and apoptotic cell numbers were elevated in ketaminetreated rats compared with control animals; these effects were prevented by the co-administration of metoprolol. The $\mathrm{NF}-\mathrm{\kappa B}$ cells were increased after ketamine treatment and sharply reduced after metoprolol administration. ${ }^{98}$ Carvedilol 
blocked in vitro human peripheral blood T-cell activation by downregulating NF- $\kappa \mathrm{B}$ activity. ${ }^{99}$ Propranolol repressed gastric cancer cell growth through downstream NF- $\kappa B^{21,32}$ Beta $_{2}-$ adrenergic antagonists suppressed the activation of NF- $\mathrm{KB}^{100}$ and potentiated the antiproliferative effects of gemcitabine by inducing apoptosis in pancreatic cancer cells. ${ }^{30}$ Taken together, the evidence indicates that $\beta$-adrenergic antagonists may suppress NF- $\mathrm{KB}$ activation in cancer.

Poly(ADP-ribose) polymerase-1 (PARP-1) is a nuclear protein that contributes to both cell death and survival under stressful conditions. PARP-1 catalytic activity is stimulated by DNA strand breaks. Parp-1-deficient cells exhibited enhanced sensitivity to the lethal effects of ionizing radiation and alkylating agents, ${ }^{101}$ whereas Parp-1 knock-out mice developed spontaneous mammary and liver tumors. ${ }^{102,103}$ The overexpression of PARP-1 has been reported in Ewing's sarcoma, ${ }^{104}$ malignant lymphomas, ${ }^{105} \mathrm{CRC},{ }^{106} \mathrm{HCC},{ }^{107}$ breast cancer, ${ }^{108}$ pediatric central nervous system tumors, ${ }^{109}$ and ovarian cancer. ${ }^{110}$ In a meta-analysis, PARP-1 mRNA expression was correlated with higher grades, medullary histological types, tumor sizes, worse metastasis-free survival rates, and decreased overall survival rates in human breast cancer. ${ }^{111}$ PARP-1 polymorphisms have been associated with gastric cancer, ${ }^{112}$ prostate cancer, ${ }^{113}$ esophageal squamous-cell carcinoma, ${ }^{114}$ and lung cancer ${ }^{115}$ in Han Chinese individuals but with a reduced risk of non-Hodgkin lymphoma in Korean males. ${ }^{116}$ PARP-1 polymorphism reduced PARP-1 catalytic activity by $30 \%-40 \% .{ }^{117} \mathrm{~A}$ meta-analysis found no significant association between $P A R P-1 V 762$ polymorphism and cancer risk. However, the $A$ variant allele of the PARP-1 V762 polymorphism was associated with an increased risk of cancer among the Asian population but a decreased risk among Caucasians, particularly with respect to glioma. ${ }^{118}$ Moreover, rabbits treated with ketamine exhibited decreased left ventricular ejection fractions, reduced ventricular conduction velocity, and increased susceptibility to ventricular arrhythmia. Metoprolol treatment prevented these pathophysiological alterations. The expression of PARP-1 and apoptosis-inducing factor were increased after ketamine treatment and sharply reduced after metoprolol administration. ${ }^{98}$ Propranolol treatment markedly suppressed PARP activation in the skeletal muscle biopsies of pediatric burn patients. ${ }^{119}$ Propranolol also protected against staurosporine-induced DNA fragmentation and PARP cleavage in SH-SY5Y neuroblastoma cells. ${ }^{120}$ The nonselective $\beta$-blocker carvedilol significantly inhibited apoptosis and suppressed activated PARP-1 cleavage in human cardiac tissue. ${ }^{121}$ Carvedilol significantly decreased ischemiareperfusion-induced poly- and mono(ADP-ribosyl)ation in heart perfusion and in a rheological model. ${ }^{122}$ Carvedilol also decreased PARP activity in the hippocampus and protected neurons against death after transient forebrain ischemia. ${ }^{123}$ Metipranolol blunted sodium nitroprusside-induced breakdown of PARP-1 in rat eyes and retinas. ${ }^{124}$ These findings suggest that PARP-1 is activated in cancer patients and $\beta$-adrenergic antagonists may have an effect on cancer by suppressing PARP-1.

Angiogenesis is a complex process that involves the coordinated steps of endothelial cell activation, proliferation, migration, tube formation, and capillary sprouting and requires the participation of many intracellular signaling pathways. VEGF is a key mediator of angiogenesis. Vascular changes associated with angiogenesis typically occur in cancer, but they have also been reported in inflammatory diseases. Statistically significant increases in VEGF expression relative to normal tissue have been reported in gastric cancer tissue, ${ }^{125}$ urothelial cell carcinoma of the urinary bladder, ${ }^{126}$ pancreatic cancer ${ }^{87}$ thyroid cancer, ${ }^{127}$ esophagogastric cancer, ${ }^{128}$ gastric cancer, ${ }^{129}$ osteosarcoma, ${ }^{130} \mathrm{HCC},{ }^{131}$ inflammatory breast cancer, ${ }^{132}$ and ovarian cancer. ${ }^{133}$ VEGF polymorphisms were found to be a critical risk factor for genetic susceptibility to lung cancers in the ethnic Han Chinese of North China. ${ }^{134}$ VEGF-A-1154GG genotype was considered to be a prognostic marker of poor survival in advanced-stage oral squamous-cell carcinoma patients. ${ }^{135}$ A meta-analysis has suggested that the $V E G F-460 T / C$, $V E G F-634 G / C$, and $V E G F-2578 C / A$ gene polymorphisms are associated with $\mathrm{CRC} .{ }^{136} \mathrm{~A}$ weak association between the $V E G F+405 G / C$ polymorphism and malignancy susceptibility was reported in an African population. ${ }^{137}$ VEGF-A and VEGF-D overexpression suggested poor prognosis in patients with gastric cancer ${ }^{138}$ and VEGF was identified as a marker of poor prognosis for patients with head and neck cancer. ${ }^{139} \mathrm{NE}$ and isoproterenol significantly enhanced VEGF production in the ovarian cell lines and cultured NPC tumor cells. These effects were blocked by the $\beta$-adrenergic antagonist propranolol, supporting a role for $\beta$-adrenergic receptors in these effects. NE also induced the invasiveness of all NPC cell lines in a dose-dependent manner, which was blocked by propranolol. ${ }^{140,141}$ Propranolol significantly decreased VEGF activity in a phorbol myristate acetate-activated human leukemic cell line. ${ }^{142}$ Further, propranolol repressed gastric cancer cell growth through downstream effects on VEGF. ${ }^{21,31}$ $\mathrm{NE}$ increased the expression of VEGF and this effect was inhibited by propranolol in pancreatic cancer cells. ${ }^{100,143}$ In addition, epinephrine enhanced the expression of VEGF in colon adenocarcinoma cells. The stimulatory action of 
adrenaline on colon cancer growth was blocked by atenolol and ICI-118,551, which are $\beta_{1}$ - and $\beta_{2}$-selective antagonists, respectively. ${ }^{143}$ These findings suggest that $\beta$-adrenergic antagonists may modulate VEGF expression in cancer.

The reduced form of nicotinamide adenine dinucleotide phosphate (NADPH) oxidase (NOX) enzyme complex mediates critical physiological and pathological processes including cell signaling, inflammation, and mitogenesis through the generation of reactive oxygen species (ROS) from molecular oxygen. It has been demonstrated that NOX1 is required for Ras oncogene-induced cell transformation. ${ }^{144}$ The NOX subunit $\mathrm{p} 22^{\text {phox }}$ was reported to inhibit the function of the tumor suppressor protein tuberin in renal carcinoma cells. ${ }^{145}$ The activation of NOXs has been demonstrated in the development of numerous cancers, including melanoma, ${ }^{146}$ leukemia, ${ }^{147}$ esophageal adenocarcinoma, ${ }^{148} \mathrm{HCC},{ }^{149}$ prostate cancer, ${ }^{150}$ colon cancer, ${ }^{151}$ glioblastoma multiforme, ${ }^{152}$ and multiple myeloma. ${ }^{153}$ NADPH polymorphisms were reportedly associated with myelodysplastic syndrome, de novo acute myeloid leukemia, ${ }^{154,155}$ esophageal cancer, ${ }^{156}$ lung cancer, ${ }^{156,157}$ non-Hodgkin lymphoma, ${ }^{158,159}$ childhood acute leukemia, ${ }^{160}$ postmenopausal breast cancer, ${ }^{161}$ and gastric cancer. ${ }^{162}$ Moreover, nebivolol, a third-generation selective $\beta$-adrenoreceptor, improved left ventricle dysfunction and survival early after myocardial ischemia and inhibited cardiac NOX activation. ${ }^{163}$ Treatment with nebivolol was associated with improvement in insulin resistance, reduced proteinuria, and decreased NOX activity/levels of ROS in kidney and skeletal muscle tissue in the transgenic TG(mRen2)27 rat. ${ }^{164,165}$ Nebivolol also improved diastolic relaxation, fibrosis, and remodeling in Zucker obese rats, with reductions in NOXdependent superoxide. ${ }^{166}$ Carvedilol attenuated the increased protein expression of NOX subunits in the heart and kidney in daunorubicin-induced cardiotoxicity and nephrotoxicity in rats. ${ }^{167}$ NOX activity in whole blood and isolated neutrophils was inhibited in a dose-dependent manner by nebivolol, whereas atenolol, metoprolol, and carvedilol were markedly less effective in Watanabe heritable hyperlipidemic rabbits. ${ }^{168}$ Celiprolol, a specific $\beta_{1}$-antagonist with weak $\beta_{2}$-agonistic action, suppressed NOX p22 $2^{\text {phox }}, \mathrm{p} 47^{\text {phox }}$, gp91 ${ }^{\text {phox }}$, and NOX1 expression in the left ventricle of deoxycorticosterone acetatesalt hypertensive rats. ${ }^{169}$ Thus, taken together, findings suggest that $\beta$-adrenergic antagonists may have a role in cancer by suppressing NADPH expression.

\section{The role of $\beta$-adrenergic blockers in cancer}

Matrix metalloproteinases (MMPs) are proteolytic enzymes that are responsible for extracellular matrix remodeling and the regulation of leukocyte migration through the extracellular matrix, an important step in inflammatory and infectious pathophysiology. MMPs are produced by many types of cells, including lymphocytes, granulocytes, astrocytes, and activated macrophages. Activation of MMPs contributes to tumor angiogenesis and metastasis. MMP-1 expression has been linked to sarcoma cell invasion. ${ }^{170} \mathrm{MMP}-2$ expression has been found increased in gastric cancer cells ${ }^{125}$ and CRC. ${ }^{171}$ MMP-9 was shown to be expressed in many cancer cells, including those associated with NSCLC, ${ }^{172}$ lymph node metastasis in human breast cancer, ${ }^{173}$ ovarian cancer invasion and metastasis, ${ }^{174}$ glioblastoma multiforme, ${ }^{175}$ and adamantinous craniopharyndioma. ${ }^{176}$ The secretion of MMP-2 and MMP-9 by leukemic cells increased the permeability of the blood-brain barrier of the central nervous system by disrupting tight junction proteins. ${ }^{177}$ In gastric cancer, MMP-2 and MMP-9 were shown to play important roles in tumor invasion and metastasis. ${ }^{178}$ The risks for the development of hypophyseal adenoma and cervical neoplasia were greater in patients with $M M P-1$ polymorphisms ${ }^{179,180}$ than in those with the wild-type allele. The $M M P-2$ polymorphism contributed to prostate cancer susceptibility in Northern India ${ }^{181}$ and to the clinical outcomes of Chinese patients with NSCLC treated with first-line platinum-based chemotherapy. ${ }^{182}$ The $M M P-7$ polymorphisms were associated with esophageal squamous-cell carcinoma, gastric cardiac adenocarcinoma, NSCLC, and CRC. ${ }^{15,160,183}$ The single-nucleotide polymorphisms (SNPs) in the MMP-2 and MMP-9 region are associated with susceptibility to head and neck squamous-cell carcinoma in an Indian population. ${ }^{184}$ The SNPs of genes encoding MMPs (MMP-1, MMP-2, MMP-3, MMP-7, MMP-8, MMP-9, MMP-12, MMP-13, and MMP-21) were shown to be related to breast cancer risk, progression, and survival. ${ }^{185}$ Based on a meta-analysis, an MMP-2 allele (-1306T) may be a protective factor against digestive cancer risk. ${ }^{186}$ The MMP-9 polymorphism was associated with a lower risk of $\mathrm{CRC}^{187}$ and polymorphisms in the promoter regions of $M M P-1$, $M M P-3, M M P-7$, and $M M P-9$ were associated with metastasis in certain cancers. ${ }^{188}$ A meta-analysis revealed that polymorphisms of $M M P-1$ (-1607) and MMP-3 (-1612) increase the risk of CRC. ${ }^{189}$ Moreover, propranolol inhibited tubulogenesis of human brain endothelial cells and MMP-9 secretion. ${ }^{190} \mathrm{~A}$ selective $\beta_{3}$-adrenoceptor agonist prevented human myometrial remodeling and the activation of MMP-2 and MMP-9 in an in vitro model of chorioamnionitis. ${ }^{191} \mathrm{NE}$ treatment increased MMP-2 and MMP-9 levels in cultured NPC tumor cells, which was inhibited by propranolol. $\mathrm{NE}$ also induced the invasiveness of all NPC cell lines in 
a dose-dependent manner, which could be blocked by an MMP inhibitor and propranolol. ${ }^{141}$ Propranolol significantly decreased MMP-2 activity in a phorbol myristate acetateactivated human leukemic cell line. ${ }^{142}$ Propranolol-induced growth inhibition was associated with $\mathrm{G}_{0} / \mathrm{G}_{1}$ arrest, $\mathrm{G}_{2} / \mathrm{M}$ arrest, and repressed gastric cancer cell growth through the downstream inhibition of MMP-2 and MMP-9. ${ }^{21} \mathrm{NE}$ increased the expression of MMP-2 and MMP-9 and these effects were inhibited by propranolol in pancreatic cancer cells. ${ }^{100,192}$ Epinephrine upregulated MMP-9 activity in human colon adenocarcinoma HT-29 cells, which was blocked by atenolol, a $\beta_{1}$-selective adrenergic antagonist, or ICI-1 18,551, a $\beta_{2}$-selective adrenergic antagonist. ${ }^{143}$ These studies suggested that $\beta$-adrenergic antagonists may play an important role in the pathological process of cancer by downregulating the level of MMPs and regulating the level of tissue inhibitors of metalloproteinases.

The MAPK pathways provide a key link between the membrane-bound receptors that receive these cues and changes in the pattern of gene expression, including the ERK cascade, the stress-activated protein kinases/c-jun N-terminal kinase (JNK) cascade, and the p38 MAPK/high osmolarity glycerol HOG cascade. ${ }^{193}$ MAPK activation was higher in renal cancer specimens than in control group specimens. Renal tumor diameter and grade increase were directly correlated with p38 MAPK expression. ${ }^{90}$ The p38 levels were significantly higher in the HCC patients with a larger tumor $(\geq 3 \mathrm{~cm}$ ) and satellite tumors, and were significantly correlated with p-JNK levels. High p38 and low p-JNK expression was associated with poor survival in HCC patients. ${ }^{194}$ Increased MAPK activity and mitogen-activated protein kinase phosphatase-1 overexpression were associated with the carcinogenesis of human gastric adenocarcinoma. ${ }^{195}$ Overexpression of the Ras and MAPK proteins (Ras p21, ERK-1, JNK-1, and p38) conferred a progressive tendency toward invasive growth, advanced-stage cancer, and decreased levels of estrogen receptor- $\alpha$ protein in advancedstage human breast cancer. ${ }^{196}$ The MAPK pathway was shown to be critical to oncogenic signaling in the majority of patients with malignant melanoma. ${ }^{197}$ The tumor suppressive actions of transforming growth factor beta-1 decreased cell viability and induced apoptosis in invasive prostate cancer and bladder cancer cells via the Akt-independent, p38 MAPK, and stress-activated protein kinases/JNKmediated activation of caspases. ${ }^{198}$ Genetic variation in the MAPK-signaling pathway influenced colorectal cancer risk and survival after diagnosis. ${ }^{199}$ Expression of the MAPK phosphatase DUSP4 was associated with microsatellite instability in $\mathrm{CRC}$ and caused increased cell proliferation. ${ }^{200}$
Moreover, the stimulation of $\beta$-adrenoceptors can activate cyclic adenosine monophosphate (cAMP)/protein kinase A (PKA) and mitogen-activated protein kinase (MAPK) pathways in pancreatic cancer cells. Pathways in pancreatic cancer cells. The $\beta_{2}$-adrenergic antagonists suppressed invasion and proliferation by inhibiting both cAMP/PKA and Ras, which regulate activation of the MAPK pathway. ${ }^{100} \mathrm{NE}$ stimulates pancreatic cancer cell proliferation, migration and invasion via $\beta$-adrenergic receptor-dependent activation of the p38 MAPK pathway. These stimulatory effects were completely stopped by propranolol or p38 MAPK-inhibitor SB203580. ${ }^{201}$ Propranolol was shown to exert its suppressive effects on hemangiomas through the hypoxia-inducible factor-1 $\alpha-$ VEGF-A-angiogenesis axis, with effects mediated by the phosphoinositide 3-kinase/Akt and p38 MAPK pathways. ${ }^{202}$ Thus, these findings suggest that $\beta$-adrenergic antagonists may have a role in cancer by suppressing the MAPK pathway.

Prostaglandins play a role in inflammatory processes. COX participates in the conversion of arachidonic acid into prostaglandins. Tumor inflammation is now recognized as one of the hallmarks of cancer. The overexpression of COX-2 is associated with resistance to apoptosis, increased angiogenesis, and increased tumor invasiveness in various cancers. Increased COX-2 expression was reported in endometrial adenocarcinoma, ${ }^{203}$ breast cancer, ${ }^{204}$ reno-medullary interstitial cell tumor, ${ }^{205} \mathrm{CRC},{ }^{206}$ gastric cancer, ${ }^{207}$ carcinoma of the cervix, ${ }^{208}$ and familial adenomatous polyposis. ${ }^{209}$ The deletion of COX-2 in mouse mammary epithelial cells delayed breast cancer onset. ${ }^{210} \mathrm{COX}-2$ inhibitors also decreased the growth and induced regression of human esophageal adenocarcinoma xenografts in nude mice ${ }^{211}$ and retarded murine mammary tumor progression by reducing tumor cell migration, invasiveness, and angiogenesis. ${ }^{212}$ Genetic variability in enzymes could have an impact on the disease risk. COX-2 polymorphisms were reported to be associated with bladder cancer, ${ }^{213}$ biliary tract cancer, ${ }^{214}$ lung cancer, ${ }^{215}$ nonmelanoma skin cancer after organ transplantation, ${ }^{216}$ esophageal squamous-cell carcinoma, ${ }^{217} \mathrm{NPC},{ }^{218}$ pancreatic cancer, ${ }^{219}$ invasive ovarian carcinoma, ${ }^{220}$ breast cancer, ${ }^{221}$ gastric carcinoma, ${ }^{222}$ acute myeloid leukemia, ${ }^{223}$ prostate cancer, ${ }^{224}$ head and neck cancer, ${ }^{225}$ colorectal adenoma, ${ }^{226}$ and HCC. ${ }^{227}$ In a meta-analysis, the $C O X-21195 G>A$ polymorphism was significantly associated with an increased risk for digestive system cancers, particularly in Asian populations. ${ }^{228}$ In addition, the $C O X-2-765 G>C$ polymorphism may have caused an increased risk of $\mathrm{CRC}$ and esophageal cancer in patients of Asian descent, whereas the $8473 T>C$ polymorphism may have caused a decreased risk of breast and lung cancer. ${ }^{229}$ In 
addition, prostaglandin $\mathrm{E}_{2}\left(\mathrm{PGE}_{2}\right)$ has been reported to be associated with colorectal adenoma, ${ }^{230}$ pancreatic tumor, ${ }^{231}$ and childhood neuroblastoma. ${ }^{232}$ Suppression of $\mathrm{PGE}_{2}$ receptors inhibited human lung carcinoma cell growth. ${ }^{233}$ Moreover, adrenaline increased $\mathrm{PGE}_{2}$ release in human colon adenocarcinoma HT-29 cells, which can be blocked by COX-2 inhibitor or by atenolol, a $\beta_{1}$-selective adrenergic antagonist, or ICI-118,551, a $\beta_{2}$-selective adrenergic antagonist. ${ }^{143}$ The $\beta_{2}$-adrenergic antagonists suppressed COX-2 expression in pancreatic cancer cells. ${ }^{100}$ Propranolol inhibits cell proliferation and represses gastric cancer cell growth through the downstream COX-2 pathway. ${ }^{21,32}$ In addition, propranolol and COX-2 inhibitor administration, which can be applied perioperatively in most cancer patients with minimal risk and at low cost, counteracted several immunologic and endocrinologic perturbations and improved recurrence-free survival rates in mice undergoing primary tumor excision. ${ }^{234,235}$ Celiprolol activates endothelial nitric oxide synthase (NOS) through the phosphatidylinositol 3-kinase/Akt pathway via NF-kB induced by oxidative stress. ${ }^{169}$ These findings suggest that $\beta$-adrenergic antagonists may play a role in modulating the inflammatory process in cancer.

ROS play a major role in various cell-signaling pathways. ROS activate various transcription factors and increase the expression of proteins that control cellular transformation, tumor cell survival, tumor cell proliferation and invasion, angiogenesis, and metastasis. ROS have been shown to play an important role in the initiation and progression of many cancers. ${ }^{236-241}$ SNPs of antioxidant defense genes may significantly modify the functional activity of encoded proteins. Women with genetic variability in the iron-related oxidative stress pathways may be at increased risk for postmenopausal breast cancer. ${ }^{242}$ The ala variant of superoxide dismutase was associated with a moderately increased risk of prostate cancer. ${ }^{243}$ Based on a meta-analysis, manganese superoxide dismutase polymorphisms may contribute to cancer development (Val-9Ala $)^{244}$ and prostate cancer susceptibility (Val-16Ala) ${ }^{245}$ but not to breast cancer susceptibility ${ }^{246}$ (Val-16Ala). Moreover, myocardial tissue sections revealed increased ROS after traumatic brain injuries. Treatment with propranolol decreased ROS levels. ${ }^{247}$ Carvedilol can modulate ROS-induced signaling. Carvedilol significantly decreased the ischemia-reperfusion-induced free-radical production and nicotinamide adenine dinucleotide catabolism, and decreased the lipid peroxidation and red blood cell membrane damage as determined by free malondialdehyde production in heart perfusion and in a rheological model. ${ }^{120}$ Nebivolol improved diastolic dysfunction and myocardial remodeling through reductions in oxidative stress in the transgenic (mRen2) rat. ${ }^{248}$ These findings suggest that $\beta$-adrenergic antagonists modulate oxidative stress in cancer.

NOS is an enzyme that is involved in the synthesis of nitric oxide (NO), which regulates a variety of important physiological responses including cell migration, immune response, and apoptosis. NO and calcium were reported to regulate mitochondrial biogenesis in follicular thyroid carcinoma cells. ${ }^{249}$ There is a link between NO and the induction of apoptotic cell death in head and neck squamouscell carcinoma. ${ }^{250}$ Cytokines, especially interferon-gamma, induced apoptosis in acute leukemia via the NO and caspase-3 pathways. ${ }^{251}$ The reduction of NO levels enhanced the radiosensitivity of hypoxic NSCLC. ${ }^{252}$ Increased NO may be a sign of subclinical cardiotoxicity of doxorubicin. ${ }^{253}$ High NO concentrations at the periphery of a melanoma may contribute to metastasis by stimulating cell proliferation, inhibiting apoptosis, or acting as a lymphangiogenic factor. ${ }^{254}$ Inducible NOS mRNA expression was considerably higher in glioblastoma specimens than in meningioma specimens. ${ }^{255}$ Inducible NOS expression has been correlated with angiogenesis, lymphangiogenesis, and poor prognosis in gastric cancer patients ${ }^{256}$ and estrogen receptor-negative breast cancer patients. ${ }^{257}$ NOS inhibition enhanced the antitumor effect of radiation in the treatment of squamous carcinoma xenografts. ${ }^{258}$ NOS polymorphisms were reported to be associated with bladder cancer, ${ }^{259}$ urothelial carcinoma, ${ }^{260}$ gastric cancer, ${ }^{261}$ colorectal cancer, ${ }^{262}$ and nonHodgkin's lymphoma. ${ }^{263}$ In a meta-analysis, endothelial NOS $894 G>T$ polymorphism was associated with breast cancer. ${ }^{264}$ Moreover, metipranolol blunted NO-induced lipid peroxidation in rat eyes and retinas. ${ }^{114}$ Nebivolol prevented vascular NOS III uncoupling in experimental hyperlipidemia. ${ }^{168}$ Propranolol suppressed hemangioma growth by inhibiting the expression of endothelial NOS protein and the subsequent production of NO. ${ }^{265}$ These findings suggest that $\beta$-adrenergic antagonists may have a role in cancer by inhibiting the expression of NOS.

\section{Conclusion}

Beta-adrenergic blockade may play a role in the prevention and treatment of cancer. Genetic studies have provided the opportunity to determine the proteins that link $\beta$-adrenergic antagonism to cancer pathology. Beta-adrenergic inhibition also exerts its effect on cancer via non-genomic mechanisms. Further investigation of the relationship between $\beta$-adrenergic antagonists and cancer is required. 


\section{Disclosure}

The authors declare no conflicts of interest in this work.

\section{References}

1. Badino GR, Novelli A, Girardi C, Di Carlo F. Evidence for functional beta-adrenoceptor subtypes in CG-5 breast cancer cell. Pharmacol Res. 1996;33(4-5):255-260.

2. Schuller HM, Cole B. Regulation of cell proliferation by beta-adrenergic receptors in a human lung adenocarcinoma cell line. Carcinogenesis. 1989;10(9):1753-1755.

3. Park PG, Merryman J, Orloff M, Schuller HM. Beta-adrenergic mitogenic signal transduction in peripheral lung adenocarcinoma: implications for individuals with preexisting chronic lung disease. Cancer Res. 1995;55(16):3504-3508.

4. Shang ZJ, Liu K, Liang de F. Expression of beta2-adrenergic receptor in oral squamous cell carcinoma. J Oral Pathol Med. 2009;38(4): 371-376.

5. Kassahun WT, Guenl B, Ungemach FR, Jonas S, Abraham G. Expression and functional coupling of liver $\beta 2$ - adrenoceptors in the human hepatocellular carcinoma. Pharmacology. 2012;89(5-6):313-320.

6. Lin X, Luo K, Lv Z, Huang J. Beta-adrenoceptor action on pancreatic cancer cell proliferation and tumor growth in mice. Hepatogastroenterology. 2012;59(114):584-588.

7. Zhao L, Yang F, Xu K, et al. Common genetic variants of the $\beta 2$-adrenergic receptor affect its translational efficiency and are associated with human longevity. Aging Cell. 2012;11(6):1094-1101.

8. Cole SW, Sood AK. Molecular pathways: beta-adrenergic signaling in cancer. Clin Cancer Res. 2012;18(5):1201-1206.

9. Lamkin DM, Sloan EK, Patel AJ, et al. Chronic stress enhances progression of acute lymphoblastic leukemia via $\beta$-adrenergic signaling. Brain Behav Immun. 2012;26(4):635-641.

10. Schuller HM, Al-Wadei HA, Ullah MF, Plummer HK 3rd. Regulation of pancreatic cancer by neuropsychological stress responses: a novel target for intervention. Carcinogenesis. 2012;33(1):191-196.

11. Al-Wadei HA, Plummer HK 3rd, Ullah MF, Unger B, Brody JR, Schuller HM. Social stress promotes and $\gamma$-aminobutyric acid inhibits tumor growth in mouse models of non-small cell lung cancer. Cancer Prev Res (Phila). 2012;5(2):189-196.

12. Liu X, Wu WK, Yu L, et al. Epinephrine stimulates esophageal squamous-cell carcinoma cell proliferation via beta-adrenoceptordependent transactivation of extracellular signal-regulated kinase/ cyclooxygenase-2 pathway. J Cell Biochem. 2008;105(1):53-60.

13. Palm D, Lang K, Niggemann B, et al. The norepinephrine-driven metastasis development of PC-3 human prostate cancer cells in BALB/c nude mice is inhibited by beta-blockers. Int J Cancer. 2006;118(11): 2744-2749.

14. Al-Wadei HA, Al-Wadei MH, Schuller HM. Cooperative regulation of non-small cell lung carcinoma by nicotinic and beta-adrenergic receptors: a novel target for intervention. PLoS One. 2012;7(1):e29915.

15. Hyltander A, Daneryd P, Sandström R, Körner U, Lundholm K. Betaadrenoceptor activity and resting energy metabolism in weight losing cancer patients. Eur J Cancer. 2000;36(3):330-334.

16. Gambardella A, Tortoriello R, Pesce L, Tagliamonte MR, Paolisso G, Varricchio M. Intralipid infusion combined with propranolol administration has favorable metabolic effects in elderly malnourished cancer patients. Metabolism. 1999;48(3):291-297.

17. Grytli HH, Fagerland MW, Fosså SD, Taskén KA, Håheim LL. Use of $\beta$-blockers is associated with prostate cancer-specific survival in prostate cancer patients on androgen deprivation therapy. Prostate. Epub July 20, 2012.

18. Diaz ES, Karlan BY, Li AJ. Impact of beta blockers on epithelial ovarian cancer survival. Gynecol Oncol. 2012;127(2):375-378.

19. De Giorgi V, Grazzini M, Gandini S, et al. Treatment with $\beta$-blockers and reduced disease progression in patients with thick melanoma. Arch Intern Med. 2011;171(8):779-781.
20. Toll L, Jimenez L, Waleh N, et al. \{Beta $\}$-adrenergic receptor agonists inhibit the proliferation of $1321 \mathrm{~N} 1$ astrocytoma cells. J Pharmacol Exp Ther. 2011;336(2):524-532.

21. Long $\mathrm{H}$, et al. Effects of propranolol in combination with radiation on apoptosis and survival of gastric cancer cells in vitro. Radiat Oncol. 2010;5:98.

22. Al-Wadei HA, Al-Wadei MH, Schuller HM. Prevention of pancreatic cancer by the beta-blocker propranolol. Anticancer Drugs. 2009;20(6): 477-482.

23. Barron TI, Connolly RM, Sharp L, Bennett K, Visvanathan K. Beta blockers and breast cancer mortality: a population- based study. J Clin Oncol. 2011;29(19):2635-2644.

24. Melhem-Bertrandt A, Chavez-Macgregor M, Lei X, et al. Betablocker use is associated with improved relapse-free survival in patients with triple-negative breast cancer. J Clin Oncol. 2011;29(19): 2645-2652.

25. Powe DG, Voss MJ, Zänker KS, et al. Beta-blocker drug therapy reduces secondary cancer formation in breast cancer and improves cancer specific survival. Oncotarget. 2010;1(7):628-638.

26. Pasquier E, Ciccolini J, Carre M, et al. Propranolol potentiates the antiangiogenic effects and anti-tumor efficacy of chemotherapy agents: implication in breast cancer treatment. Oncotarget. 2011;2(10): 797-809.

27. Campbell JP, Karolak MR, Ma Y, et al. Stimulation of host bone marrow stromal cells by sympathetic nerves promotes breast cancer bone metastasis in mice. PLoS Biol. 2012;10(7):e1001363.

28. Nkontchou G, Aout M, Mahmoudi A, et al. Effect of long-term propranolol treatment on hepatocellular carcinoma incidence in patients with HCV-associated cirrhosis. Cancer Prev Res (Phila). 2012;5(8): 1007-1014.

29. Stanojkovic TP, Zizak Z, Mihailovic-Stanojevic N, Petrovic T, Juranic Z. Inhibition of proliferation on some neoplastic cell lines-act of carvedilol and captopril. J Exp Clin Cancer Res. 2005;24(3):387-395.

30. Shan T, Ma Q, Zhang D, et al. $\beta 2$-adrenoceptor blocker synergizes with gemcitabine to inhibit the proliferation of pancreatic cancer cells via apoptosis induction. Eur J Pharmacol. 2011;665(1-3):1-7.

31. Maturo S, Tse SM, Kinane TB, Hartnick CJ. Initial experience using propranolol as an adjunctive treatment in children with aggressive recurrent respiratory papillomatosis. Ann Otol Rhinol Laryngol. 2011; 120(1):17-20.

32. Liao X, Che X, Zhao W, Zhang D, Bi T, Wang G. The $\beta$-adrenoceptor antagonist, propranolol, induces human gastric cancer cell apoptosis and cell cycle arrest via inhibiting nuclear factor $\mathrm{\kappa B}$ signaling. Oncol Rep. 2010;24(6):1669-1676.

33. Kozanoglu I, Yandim MK, Cincin ZB, Ozdogu H, Cakmakoglu B, Baran Y. New indication for therapeutic potential of an old well-known drug (propranolol) for multiple myeloma. J Cancer Res Clin Oncol. 2012. Epub Oct 19.

34. Raffegerst SH, Hoelzlwimmer G, Kunder S, Mysliwietz J, QuintanillaMartinez L, Schendel DJ. Diverse hematological malignancies including hodgkin-like lymphomas develop in chimeric MHC class II transgenic mice. PLoS One. 2009;4(12):e8539.

35. García-Plata D, Mozos E, Carrasco L, Solana R. HLA molecule expression in cutaneous squamous cell carcinomas: an immunopathological study and clinical-immunohistopathological correlations. Histol Histopathol. 1993;8(2):219-226.

36. Makni H, Daoud J, Ben Salah H, et al. HLA association with nasopharyngeal carcinoma in southern Tunisia. Mol Biol Rep. 2010;37(5): 2533-2539.

37. Panza N, Del Vecchio L, Maio M, et al. Strong association between an HLA-DR antigen and thyroid carcinoma. Tissue Antigens. 1982;20(2): $155-158$.

38. Lindhorst E, Schumm-Draeger PM, Bojunga J, Usadel KH, Herrmann G. Differences in tumor cell proliferation, HLA DR expression and lymphocytic infiltration in various types of thyroid carcinoma. Exp Clin Endocrinol Diabetes. 2002;110(1):27-31.

39. Donaldson PT, Ho S, Williams R, Johnson PJ. HLA class II alleles in Chinese patients with hepatocellular carcinoma. Liver. 2001;21(2): $143-148$. 
40. Lee HW, Hahm KB, Lee JS, Ju YS, Lee KM, Lee KW. Association of the human leukocyte antigen class II alleles with chronic atrophic gastritis and gastric carcinoma in Koreans. J Dig Dis. 2009;10(4): 265-271.

41. Ando T, Ishikawa T, Kato H, et al. Synergistic effect of HLA class II loci and cytokine gene polymorphisms on the risk of gastric cancer in Japanese patients with Helicobacter pylori infection. Int $J$ Cancer. 2009;125(11):2595-2602.

42. Michel S, Linnebacher M, Alcaniz J, et al. Lack of HLA class II antigen expression in microsatellite unstable colorectal carcinomas is caused by mutations in HLA class II regulatory genes. Int J Cancer. 2010; 127(4):889-898

43. Hernández-Hernández DM, Cerda-Flores RM, Juárez-Cedillo T, et al. Human leukocyte antigens I and II haplotypes associated with human papillomavirus 16-positive invasive cervical cancer in Mexican women. Int J Gynecol Cancer. 2009;19(6):1099-1106.

44. Ozdemir E, Kakehi Y, Mishina M, et al. High-resolution HLA-DRB1 and DQB1 genotyping in Japanese patients with testicular germ cell carcinoma. Br J Cancer. 1997;76(10):1348-1352.

45. Choi HB, Roh SY, Choi EJ, et al. Association of HLA alleles with nonHodgkin's lymphoma in Korean population. Int J Hematol. 2008;87(2): 203-209.

46. Ozdilli K, Oguz FS, Anak S, Kekik C, Carin M, Gedikoglu G. The frequency of HLA class I and II alleles in Turkish childhood acute leukaemia patients. J Int Med Res. 2010;38(5):1835-1844.

47. Naugler C, Liwski R. HLA risk markers for chronic myelogenous leukemia in Eastern Canada. Leuk Lymphoma. 2009;50(2):254-259.

48. Hojjat-Farsangi M, Jeddi-Tehrani M, Amirzargar AA, et al. Human leukocyte antigen class II allele association to disease progression in Iranian patients with chronic lymphocytic leukemia. Hum Immunol. 2008;69(10):666-674.

49. Limas CJ, Goldenberg IF, Limas C. Influence of anti-beta-receptor antibodies on cardiac adenylate cyclase in patients with idiopathic dilated cardiomyopathy. Am Heart J. 1990;119(6):1322-1328.

50. Li Q, Milo R, Panitch H, Bever CT Jr. Effect of propranolol and IFN-beta on the induction of MHC class II expression and cytokine production by IFN-gamma IN THP-1 human monocytic cells. Immunopharmacol Immunotoxicol. 1998;20(1):39-61.

51. Shaw SM, Coppinger T, Waywell C, et al. The effect of beta-blockers on the adaptive immune system in chronic heart failure. Cardiovasc Ther. 2009;27(3):181-186.

52. Johnston CI. Tissue angiotensin converting enzyme in cardiac and vascular hypertrophy, repair, and remodeling. Hypertension. 1994;23(2): $258-268$.

53. Deshayes F, Nahmias C. Angiotensin receptors: a new role in cancer? Trends Endocrinol Metab. 2005;16(7):293-299.

54. Lotfy M, El-Kenawy Ael-M, Abdel-Aziz MM, El-Kady I, Talaat A. Elevated renin levels in patients with liver cirrhosis and hepatocellular carcinoma. Asian Pac J Cancer Prev. 2010;11(5):1263-1266.

55. Beyazit Y, Purnak T, Suvak B, et al. Increased ACE in extrahepatic cholangiocarcinoma as a clue for activated RAS in biliary neoplasms. Clin Res Hepatol Gastroenterol. 2011;35(10):644-649.

56. Aksu S, Beyazit Y, Haznedaroglu IC, et al. Over-expression of angiotensin-converting enzyme (CD 143) on leukemic blasts as a clue for the activated local bone marrow RAS in AML. Leuk Lymphoma. 2006;47(5):891-896.

57. Koca E, Haznedaroglu IC, Uner A, Sayinalp N, Saglam AE, et al. Angiotensin-converting enzyme expression of the lymphoma-associated macrophages in the lymph nodes of Hodgkin's disease. J Natl Med Assoc. 2007;99(11):1243-1244, 1246-1247.

58. Huang W, Yu LF, Zhong J, et al. Angiotensin II type 1 receptor expression in human gastric cancer and induces MMP2 and MMP9 expression in MKN-28 cells. Dig Dis Sci. 2008;53(1): $163-168$.

59. Louis SN, Wang L, Chow L, et al. Appearance of angiotensin II expression in non-basal epithelial cells is an early feature of malignant change in human prostate. Cancer Detect Prev. 2007;31(5):391-395.
60. Feng Y, Ni L, Wan H, et al. Overexpression of ACE2 produces antitumor effects via inhibition of angiogenesis and tumor cell invasion in vivo and in vitro. Oncol Rep. 2011;26(5):1157-1164.

61. Ino K, Shibata K, Kajiyama H, et al. Angiotensin II type 1 receptor expression in ovarian cancer and its correlation with tumour angiogenesis and patient survival. Br J Cancer. 2006;94(4):552-560.

62. Volante M, Rapa I, Gandhi M, et al. RAS mutations are the predominant molecular alteration in poorly differentiated thyroid carcinomas and bear prognostic impact. J Clin Endocrinol Metab. 2009;94(12):4735-4741.

63. Alves Corrêa SA, Ribeiro de Noronha SM, Nogueira-de-Souza NC, et al. Association between the angiotensin-converting enzyme (insertion/ deletion) and angiotensin II type 1 receptor (A1166C) polymorphisms and breast cancer among Brazilian women. J Renin Angiotensin Aldosterone Syst. 2009;10(1):51-58.

64. González-Zuloeta Ladd AM, Arias Vásquez A, Sayed-Tabatabaei FA, Coebergh JW, Hofman A, et al. Angiotensin-converting enzyme gene insertion/deletion polymorphism and breast cancer risk. Cancer Epidemiol Biomarkers Prev. 2005;14(9):2143-2146.

65. van der Knaap R, Siemes C, Coebergh JW, van Duijn CM, Hofman A, Stricker BH. Renin-angiotensin system inhibitors, angiotensin I-converting enzyme gene insertion/deletion polymorphism, and cancer: the Rotterdam Study. Cancer. 2008;112(4):748-757.

66. Wang X, Wang S, Lin YW, et al. Angiotensin-converting enzyme insertion/deletion polymorphism and the risk of prostate cancer in the Han population of China. Med Oncol. 2012;29(3):1964-1971.

67. Feng Y, Wan H, Liu J, et al. The angiotensin-converting enzyme 2 in tumor growth and tumor-associated angiogenesis in non-small cell lung cancer. Oncol Rep. 2010;23(4):941-948.

68. Zhou L, Zhang R, Yao W, Wang J, Qian A, et al. Decreased expression of angiotensin-converting enzyme 2 in pancreatic ductal adenocarcinoma is associated with tumor progression. Tohoku J Exp Med. 2009;217(2): 123-131.

69. Zhou L, Zhang R, Zhang L, Yao W, Li J, Yuan Y. Angiotensinconverting enzyme 2 acts as a potential molecular target for pancreatic cancer therapy. Cancer Lett. 2011;307(1):18-25.

70. Kinoshita J, Fushida S, Harada S, et al. Local angiotensin II-generation in human gastric cancer: correlation with tumor progression through the activation of ERK1/2, NF-kappaB and survivin. Int $J$ Oncol. 2009;34(6):1573-1582.

71. Du N, Feng J, Hu LJ, et al. Angiotensin II receptor type 1 blockers suppress the cell proliferation effects of angiotensin II in breast cancer cells by inhibiting AT1R signaling. Oncol Rep. 2012;27(6):1893-1903.

72. Wilop S, von Hobe S, Crysandt M, Esser A, Osieka R, Jost E. Impact of angiotensin I converting enzyme inhibitors and angiotensin II type 1 receptor blockers on survival in patients with advanced non-smallcell lung cancer undergoing first-line platinum-based chemotherapy. $J$ Cancer Res Clin Oncol. 2009;135(10):1429-1435.

73. Nakai $\mathrm{Y}$, Isayama H, Ijichi H, et al. Inhibition of renin-angiotensin system affects prognosis of advanced pancreatic cancer receiving gemcitabine. Br J Cancer. 2010;103(11):1644-1648.

74. Keizman D, Huang P, Eisenberger MA, et al. Angiotensin system inhibitors and outcome of sunitinib treatment in patients with metastatic renal cell carcinoma: a retrospective examination. Eur J Cancer. 2011;47(13): 1955-1961.

75. Ming M, Wu J, Lachance S, Delalandre A, Carrière S, Chan JS. Betaadrenergic receptors and angiotensinogen gene expression in mouse hepatoma cells in vitro. Hypertension. 1995;25(1):105-109.

76. Nakamaru M, Jackson EK, Inagami T. Beta-adrenoceptor-mediated release of angiotensin II from mesenteric arteries. Am J Physiol. 1986; 250(1 Pt 2):H144-H148.

77. Richards EM, Hermann K, Sumners C, Raizada MK, Phillips MI. Release of immunoreactive angiotensin II from neuronal cultures: adrenergic influences. Am J Physiol. 1989;257(3 Pt 1):C588-C595.

78. Tang SS, Stevenson L, Dzau VJ. Endothelial renin-angiotensin pathway. Adrenergic regulation of angiotensin secretion. Circ Res. 1990;66(1): 103-108. 
79. Taddei S, Favilla S, Duranti P, Simonini N, Salvetti A. Vascular reninangiotensin system and neurotransmission in hypertensive persons. Hypertension. 1991;18(3):266-277.

80. Vilas-Boas WW, Ribeiro-Oliveira A Jr, Ribeiro Rda C, et al. Effect of propranolol on the splanchnic and peripheral renin angiotensin system in cirrhotic patients. World J Gastroenterol. 2008;14(44): 6824-6830.

81. Saijonmaa O, Nyman T, Fyhrquist F. Carvedilol inhibits basal and stimulated ACE production in human endothelial cells. J Cardiovasc Pharmacol. 2004;43(5):616-621.

82. Cohen Solal A, Jondeau G, Beauvais F, Berdeaux A. Beneficial effects of carvedilol on angiotensin-converting enzyme activity and renin plasma levels in patients with chronic heart failure. Eur J Heart Fail. 2004;6(4):463-466.

83. Itinteang T, Brasch HD, Tan ST, Day DJ. Expression of components of the renin-angiotensin system in proliferating infantile haemangioma may account for the propranolol-induced accelerated involution. J Plast Reconstr Aesthet Surg. 2011;64(6):759-765.

84. Léauté-Labrèze C, Dumas de la Roque E, Hubiche T, Boralevi F, Thambo JB, Taïeb A. Propranolol for severe hemangiomas of infancy. N Engl J Med. 2008;358(24):2649-2651.

85. Sans V, de la Roque ED, Berge J, et al. Propranolol for severe infantile hemangiomas: follow-up report. Pediatrics. 2009;124(3): e423-e431.

86. Shukla S, MacLennan GT, Fu P, et al. Nuclear factor-kappaB/p65 (Rel A) is constitutively activated in human prostate adenocarcinoma and correlates with disease progression. Neoplasia. 2004;6(4): 390-400.

87. Furukawa K, Uwagawa T, Haruki K, et al. Nuclear factor $\kappa \mathrm{B}$ activity correlates with the progression and prognosis of pancreatic cancer in a mouse model. Surg Today. 2012. Epub Aug 15.

88. Ozbek E, Aliskan T, Otunctemur A, et al. Comparison of tumor grade and stage with nuclear factor kappa $\mathrm{b}$ and p38 mitogene activated protein kinase expressions in renal cell cancer. Arch Ital Urol Androl. 2012;84(2):53-60.

89. Spirina LV, Yunusova NV, Kondakova IV, et al. Association of growth factors, HIF-1 and NF- $\kappa$ B expression with proteasomes in endometrial cancer. Mol Biol Rep. 2012;39(9):8655-8662.

90. Spiller SE, Logsdon NJ, Deckard LA, Sontheimer H. Inhibition of nuclear factor kappa-B signaling reduces growth in medulloblastoma in vivo. BMC Cancer. 2011;11:136.

91. Yu Y, Liu H, Jin M, et al. The joint association of REST and NFKB1 polymorphisms on the risk of colorectal cancer. Ann Hum Genet. 2012;76(4):269-276.

92. Lin CW, Hsieh YS, Hsin CH, et al. Effects of NFKB1 and NFKBIA gene polymorphisms on susceptibility to environmental factors and the clinicopathologic development of oral cancer. PLoS One. 2012;7(4):e35078.

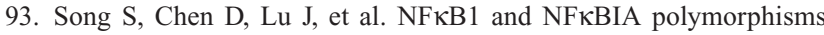
are associated with increased risk for sporadic colorectal cancer in a southern Chinese population. PLoS One. 2011;6(6):e21726.

94. Wang X, Lu P, Xu L, et al. Updated meta-analysis of NFkappaB1-94 ins/ Delattg promoter polymorphism and cancer risk based on 19 casecontrol studies. Asian Pac J Cancer Prev. 2011;12(10):2479-2484.

95. Fan Y, Yu W, Ye P, Wang H, Wang Z, et al. NFKB1 insertion/deletion promoter polymorphism increases the risk of advanced ovarian cancer in a Chinese population. DNA Cell Biol. 2011;30(4):241-245.

96. Zhou B, Qie M, Wang Y, et al. Relationship between NFKB194 insertion/deletion ATTG polymorphism and susceptibility of cervical squamous cell carcinoma risk. Ann Oncol. 2010;21(3): 506-511.

97. Wang S, Zhang M, Zeng Z, et al. IאB $\alpha$ polymorphisms were associated with increased risk of gastric cancer in a southern Chinese population: a case-control study. Life Sci. 2011;88(17-18):792-797.

98. Li Y, Shi J, Yang BF, et al. Ketamine-induced ventricular structural, sympathetic and electrophysiological remodelling: pathological consequences and protective effects of metoprolol. Br J Pharmacol. 2012; 165(6):1748-1756.
99. Yang SP, Ho LJ, Lin YL, et al. Carvedilol, a new antioxidative betablocker, blocks in vitro human peripheral blood $\mathrm{T}$ cell activation by downregulating NF-kappaB activity. Cardiovasc Res. 2003;59(3): 776-787.

100. Zhang D, Ma QY, Hu HT, Zhang M. $\beta 2$-adrenergic antagonists suppress pancreatic cancer cell invasion by inhibiting $\mathrm{CREB}, \mathrm{NF} \kappa \mathrm{B}$ and AP-1. Cancer Biol Ther. 2010;10(1):19-29.

101. Masutani M, Nakagama H, Sugimura T. Poly(ADP-ribose) and carcinogenesis. Genes Chromosomes Cancer. 2003;38(4):339-348.

102. Tong WM, Yang YG, Cao WH, et al. Poly(ADP-ribose) polymerase-1 plays a role in suppressing mammary tumourigenesis in mice. Oncogene. 2007;26(26):3857-3867.

103. Tong WM, Cortes U, Hande MP, et al. Synergistic role of Ku80 and poly(ADP-ribose) polymerase in suppressing chromosomal aberrations and liver cancer formation. Cancer Res. 2002;62(23):6990-6996.

104. Prasad SC, Thraves PJ, Bhatia KG, Smulson ME, Dritschilo A Enhanced poly(adenosine diphosphate ribose) polymerase activity and gene expression in Ewing's sarcoma cells. Cancer Res. 1990;50(1): $38-43$.

105. Tomoda T, Kurashige T, Moriki T, Yamamoto H, Fujimoto S, Taniguchi T. Enhanced expression of poly(ADP-ribose) synthetase gene in malignant lymphoma. Am J Hematol. 1991;37(4):223-227.

106. Nosho K, Yamamoto H, Mikami M, et al. Overexpression of poly(ADP-ribose) polymerase-1 (PARP-1) in the early stage of colorectal carcinogenesis. Eur J Cancer. 2006;42(14):2374-2381.

107. Quiles-Perez R, Muñoz-Gámez JA, Ruiz-Extremera A, et al. Inhibition of poly adenosine diphosphate-ribose polymerase decreases hepatocellular carcinoma growth by modulation of tumor-related gene expression. Hepatology. 2010;51(1):255-266.

108. Rojo F, García-Parra J, Zazo S, et al. Nuclear PARP-1 protein overexpression is associated with poor overall survival in early breast cancer. Ann Oncol. 2012;23(5):1156-1164.

109. Barton VN, Donson AM, Kleinschmidt-DeMasters BK, Gore L, Liu AK, Foreman NK. PARP1 expression in pediatric central nervous system tumors. Pediatr Blood Cancer. 2009;53(7):1227-1230.

110. Barnett JC, Bean SM, Nakayama JM, Kondoh E, Murphy SK, Berchuck A. High poly(adenosine diphosphate-ribose) polymerase expression and poor survival in advanced-stage serous ovarian cancer. Obstet Gynecol. 2010;115(1):49-54

111. Gonçalves A, Finetti P, Sabatier R, et al. Poly(ADP-ribose) polymerase-1 mRNA expression in human breast cancer: a metaanalysis. Breast Cancer Res Treat. 2011;127(1):273-281.

112. Zhang Q, Li Y, Li X, et al. PARP-1 Val762Ala polymorphism, $\mathrm{CagA}+\mathrm{H}$. pylori infection and risk for gastric cancer in Han Chinese population. Mol Biol Rep. 2009;36(6):1461-1467.

113. Lockett KL, Hall MC, Xu J, et al. The ADPRT V762A genetic variant contributes to prostate cancer susceptibility and deficient enzyme function. Cancer Res. 2004;64(17):6344-6348.

114. Hao B, Wang H, Zhou K, et al. Identification of genetic variants in base excision repair pathway and their associations with risk of esophageal squamous cell carcinoma. Cancer Res. 2004;64(12):4378-4384.

115. Zhang J, Jin X, Fang S, et al. The functional polymorphism in the matrix metalloproteinase-7 promoter increases susceptibility to esophageal squamous cell carcinoma, gastric cardiac adenocarcinoma and non-small cell lung carcinoma. Carcinogenesis. 2005;26(10):1748-1753.

116. Jin XM, Kim HN, Lee IK, Park KS, Kim HJ, et al. PARP-1 Val762Ala polymorphism is associated with reduced risk of non-Hodgkin lymphoma in Korean males. BMC Med Genet. 2010;11:38.

117. Wang XG, Wang ZQ, Tong WM, Shen Y. PARP1 Val762Ala polymorphism reduces enzymatic activity. Biochem Biophys Res Commun. 2007;354(1):122-126.

118. Yu H, Ma H, Yin M, Wei Q. Association between PARP-1 V762A polymorphism and cancer susceptibility: a meta-analysis. Genet Epidemiol. 2011;36(1):56-65.

119. Oláh G, Finnerty CC, Sbrana E, et al. Increased poly(ADP-ribosyl)ation in skeletal muscle tissue of pediatric patients with severe burn injury: prevention by propranolol treatment. Shock. 2011;36(1):18-23. 
120. Mikami M, Goubaeva F, Song JH, Lee HT, Yang J. beta-Adrenoceptor blockers protect against staurosporine-induced apoptosis in $\mathrm{SH}-$ SY5Y neuroblastoma cells. Eur J Pharmacol. 2008;589(1-3): 14-21.

121. Usta E, Mustafi M, Straub A, Ziemer G. The nonselective betablocker carvedilol suppresses apoptosis in human cardiac tissue: a pilot study. Heart Surg Forum. 2010;13(4):E218-E222.

122. Habon T, Szabados E, Kesmarky G, et al. The effect of carvedilol on enhanced ADP-ribosylation and red blood cell membrane damage caused by free radicals. Cardiovasc Res. 2001;52(1): 153-160.

123. Strosznajder RP, Jesko H, Dziewulska J. Effect of carvedilol on neuronal survival and poly(ADP-ribose) polymerase activity in hippocampus after transient forebrain ischemia. Acta Neurobiol Exp (Wars). 2005;65(2):137-143.

124. Osborne NN, Wood JP. Metipranolol blunts nitric oxide-induced lipid peroxidation and death of retinal photoreceptors: a comparison with other anti-glaucoma drugs. Invest Ophthalmol Vis Sci. 2004;45(10):3787-3795.

125. Partyka R, Gonciarz M, Jałowiecki P, Kokocińska D, Byrczek T. VEGF and metalloproteinase 2 (MMP 2) expression in gastric cancer tissue. Med Sci Monit. 2012;18(4):BR130-BR134.

126. Zaravinos A, Volanis D, Lambrou GI, Delakas D, Spandidos DA. Role of the angiogenic components, VEGFA, FGF2, OPN and RHOC, in urothelial cell carcinoma of the urinary bladder. Oncol Rep. 2012;28(4):1159-1166.

127. Zhou ZH, Cui XN, Xing HG, Yan RH, Yao DK, Wang LX. Changes and Prognostic Value of Serum Vascular Endothelial Growth Factor in Patients with Differentiated Thyroid Cancer. Med Princ Pract. Epub August 8, 2012.

128. Gray RT, O’Donnell ME, McGuigan JA, Spence GM. Quantification of tumour and circulating vascular endothelial growth factor (VEGF) in patients with oesophagogastric cancer: a long-term follow-up study. Br J Biomed Sci. 2012;69(2):71-75.

129. Villarejo-Campos P, Padilla-Valverde D, Martin RM, et al. Serum VEGF and VEGF-C values before surgery and after postoperative treatment in gastric cancer. Clin Transl Oncol. Epub July 24, 2012.

130. Lammli J, Fan M, Rosenthal HG, et al. Expression of Vascular Endothelial Growth Factor correlates with the advance of clinical osteosarcoma. Int Orthop. 2012;36(11):2307-2313.

131. Yen CJ, Lin YJ, Yen CS, et al. Hepatitis B virus X protein upregulates mTOR signaling through IKK $\beta$ to increase cell proliferation and VEGF production in hepatocellular carcinoma. PLoS One. 2012;7(7): e41931.

132. Arias-Pulido H, Chaher N, Gong Y, Qualls C, Vargas J, Royce M. Tumor stromal vascular endothelial growth factor A is predictive of poor outcome in inflammatory breast cancer. BMC Cancer. 2012;12: 298.

133. Bandiera E, Franceschini R, Specchia C, et al. Prognostic significance of vascular endothelial growth factor serum determination in women with ovarian cancer. ISRN Obstet Gynecol. 2012;2012: 245756.

134. Li Y, Liang J, Liu X, et al. Correlation of polymorphisms of the vascular endothelial growth factor gene and the risk of lung cancer in an ethnic Han group of North China. Exp Ther Med. 2012;3(4): 673-676.

135. Supic G, Jovic N, Zeljic K, Kozomara R, Magic Z. Association of VEGF-A genetic polymorphisms with cancer risk and survival in advanced-stage oral squamous cell carcinoma patients. Oral Oncol. 2012;48(11):1171-1177.

136. Zhao Z, Ba C, Wang W, Wang X, Xue R, Wu X. Vascular endothelial growth factor (VEGF) gene polymorphisms and colorectal cancer: a meta-analysis of epidemiologic studies. Genet Test Mol Biomarkers. 2012;16(12):1390-1394.
137. Hu K, Zhang Y, Wang R, Li G, Li G, Zhang D. Current evidence on VEGF+405G/C polymorphism and malignancy susceptibility: a meta-analysis involving 30 studies. Twin Res Hum Genet. 2012;15(4): 496-502.

138. Peng L, Zhan P, Zhou Y, et al. Prognostic significance of vascular endothelial growth factor immunohistochemical expression in gastric cancer: a meta-analysis. Mol Biol Rep. 2012;39(10):9473-9484.

139. Zang J, Li C, Zhao LN, et al. Prognostic value of vascular endothelial growth factor in patients with head and neck cancer: A meta-analysis. Head Neck. Epub September 18, 2012.

140. Lutgendorf SK, Cole S, Costanzo E, et al. Stress-related mediators stimulate vascular endothelial growth factor secretion by two ovarian cancer cell lines. Clin Cancer Res. 2003;9(12):4514-4521.

141. Yang EV, Sood AK, Chen M, et al. Norepinephrine up-regulates the expression of vascular endothelial growth factor, matrix metalloproteinase (MMP)-2, and MMP-9 in nasopharyngeal carcinoma tumor cells. Cancer Res. 2006;66(21):10357-10364.

142. Hajighasemi F, Hajighasemi S. Effect of propranolol on angiogenic factors in human hematopoietic cell lines in vitro. Iran Biomed J. 2009;13(4):223-228.

143. Wong HP, Ho JW, Koo MW, et al. Effects of adrenaline in human colon adenocarcinoma HT-29 cells. Life Sci. 2011;88(25-26):1108-1112.

144. Kamata T. Roles of Nox 1 and other Nox isoforms in cancer development. Cancer Sci. 2009;100(8):1382-1388.

145. Block K, Gorin Y, New DD, et al. The NADPH oxidase subunit $\mathrm{p} 22$ phox inhibits the function of the tumor suppressor protein tuberin. Am J Pathol. 2010;176(5):2447-2455.

146. Yamaura M, Mitsushita J, Furuta S, et al. NADPH oxidase 4 contributes to transformation phenotype of melanoma cells by regulating G2-M cell cycle progression. Cancer Res. 2009;69(6):2647-2654.

147. Maraldi T, Prata C, Vieceli Dalla Sega F, et al. NAD $(\mathrm{P}) \mathrm{H}$ oxidase isoform Nox2 plays a prosurvival role in human leukaemia cells. Free Radic Res. 2009;43(11):1111-1121.

148. Hong J, Resnick M, Behar J, et al. Acid-induced p16 hypermethylation contributes to development of esophageal adenocarcinoma via activation of NADPH oxidase NOX5-S. Am J Physiol Gastrointest Liver Physiol. 2010;299(3):G697-G706.

149. Lu CL, Qiu JL, Huang PZ, et al. NADPH oxidase DUOX1 and DUOX2 but not NOX4 are independent predictors in hepatocellular carcinoma after hepatectomy. Tumour Biol. 2011;32(6):1173-1182.

150. Kim J, Koyanagi T, Mochly-Rosen D. PKC $\delta$ activation mediates angiogenesis via NADPH oxidase activity in PC-3 prostate cancer cells. Prostate. 2011;71(9):946-954.

151. Wang R, Dashwood WM, Nian H, et al. NADPH oxidase overexpression in human colon cancers and rat colon tumors induced by 2-amino-1-methyl-6-phenylimidazo[4,5-b]pyridine (PhIP). Int $J$ Cancer. 2011;128(11):2581-2590.

152. Hsieh CH, Shyu WC, Chiang CY, Kuo JW, Shen WC, Liu RS. NADPH oxidase subunit 4-mediated reactive oxygen species contribute to cycling hypoxia-promoted tumor progression in glioblastoma multiforme. PLoS One. 2011;6(9):e23945.

153. Yin L, Kosugi M, Kufe D. Inhibition of the MUC1-C oncoprotein induces multiple myeloma cell death by down-regulating TIGAR expression and depleting NADPH. Blood. 2012;119(3): $810-816$.

154. Naoe T, Takeyama K, Yokozawa T, et al. Analysis of genetic polymorphism in NQO1, GST-M1, GST-T1, and CYP3A4 in 469 Japanese patients with therapy-related leukemia/myelodysplastic syndrome and de novo acute myeloid leukemia. Clin Cancer Res. 2000;6(10): 4091-4095.

155. Fern L, Pallis M, Ian Carter G, Seedhouse C, Russell N, Byrne J. Clonal haemopoiesis may occur after conventional chemotherapy and is associated with accelerated telomere shortening and defects in the NQO1 pathway; possible mechanisms leading to an increased risk of t-AML/MDS. Br J Haematol. 2004;126(1):63-71. 
156. Hamajima N, Matsuo K, Iwata $\mathrm{H}$, et al. $\mathrm{NAD}(\mathrm{P}) \mathrm{H}$ : quinone oxidoreductase 1 (NQO1) C609T polymorphism and the risk of eight cancers for Japanese. Int J Clin Oncol. 2002;7(2):103-108.

157. Chan EC, Lam SY, Fu KH, Kwong YL. Polymorphisms of the GSTM1, GSTP1, MPO, XRCC1, and NQO1 genes in Chinese patients with nonsmall cell lung cancers: relationship with aberrant promoter methylation of the CDKN2A and RARB genes. Cancer Genet Cytogenet. 2005;162(1):10-20.

158. Lan Q, Zheng T, Shen M, et al. Genetic polymorphisms in the oxidative stress pathway and susceptibility to non-Hodgkin lymphoma. Hum Genet. 2007;121(2):161-168.

159. Hoffmann M, Schirmer MA, Tzvetkov MV, et al; German Study Group for High-Grade Non-Hodgkin Lymphoma. A functional polymorphism in the $\mathrm{NAD}(\mathrm{P}) \mathrm{H}$ oxidase subunit CYBA is related to gene expression, enzyme activity, and outcome in non-Hodgkin lymphoma. Cancer Res. 2010;70(6):2328-2338.

160. Gra OA, Glotov AS, Kozhekbaeva ZH, Makarova OV, Nasedkina TV. Genetic polymorphism in GST, NAT2, and MTRR and susceptibility to childhood acute leukemia. Mol Biol (Mosk). 2008;42(2):214-225. Russian.

161. Seibold P, Hein R, Schmezer P, et al. Polymorphisms in oxidative stress-related genes and postmenopausal breast cancer risk. Int $J$ Cancer. 2011;129(6):1467-1476.

162. Malik MA, Sharma KL, Zargar SA, Mittal B. Association of matrix metalloproteinase-7 $(-181 \mathrm{~A}>\mathrm{G})$ polymorphism with risk of esophageal squamous cell carcinoma in Kashmir Valley. Saudi J Gastroenterol. 2011;17(5):301-306.

163. Sorrentino SA, Doerries C, Manes C, et al. Nebivolol exerts beneficial effects on endothelial function, early endothelial progenitor cells, myocardial neovascularization, and left ventricular dysfunction early after myocardial infarction beyond conventional $\beta 1$-blockade. $J$ Am Coll Cardiol. 2011;57(5):601-611.

164. Manrique C, Lastra G, Habibi J, et al. Nebivolol improves insulin sensitivity in the TGR(Ren2)27 rat. Metabolism. 2011;60(12):1757-1766.

165. Whaley-Connell A, Habibi J, Johnson M, et al. Nebivolol reduces proteinuria and renal NADPH oxidase-generated reactive oxygen species in the transgenic Ren2 rat. Am J Nephrol. 2009;30(4):354-360.

166. Zhou X, Ma L, Habibi J, et al. Nebivolol improves diastolic dysfunction and myocardial remodeling through reductions in oxidative stress in the Zucker obese rat. Hypertension. 2010;55(4):880-888.

167. Arozal W, Watanabe K, Veeraveedu PT, et al. Protective effect of carvedilol on daunorubicin-induced cardiotoxicity and nephrotoxicity in rats. Toxicology. 2010;274(1-3):18-26.

168. Mollnau H, Schulz E, Daiber A, et al. Nebivolol prevents vascular NOS III uncoupling in experimental hyperlipidemia and inhibits NADPH oxidase activity in inflammatory cells. Arterioscler Thromb Vasc Biol. 2003;23(4):615-621.

169. Kobayashi N, Mita S, Yoshida K, et al. Celiprolol activates eNOS through the PI3K-Akt pathway and inhibits VCAM-1 Via NF-kappaB induced by oxidative stress. Hypertension. 2003;42(5): 1004-1013.

170. Garamszegi N, Garamszegi SP, Scully SP. Matrix metalloproteinase-1 contribution to sarcoma cell invasion. J Cell Mol Med. 2012;16(6): $1331-1341$

171. Dong W, Li H, Zhang Y, et al. Matrix metalloproteinase 2 promotes cell growth and invasion in colorectal cancer. Acta Biochim Biophys Sin (Shanghai). 2011;43(11):840-848.

172. Peng WJ, Zhang JQ, Wang BX, Pan HF, Lu MM, Wang J. Prognostic value of matrix metalloproteinase 9 expression in patients with non-small cell lung cancer. Clin Chim Acta. 2012;413(13-14):1121-1126.

173. Qiu J, Shao S, Yang G, Shen Z, Zhang Y. Association of Toll like receptor 9 expression with lymph node metastasis in human breast cancer. Neoplasma. 2011;58(3):251-255.

174. Zhang W, Yang HC, Wang Q, et al. Clinical value of combined detection of serum matrix metalloproteinase-9, heparanase, and cathepsin for determining ovarian cancer invasion and metastasis. Anticancer Res. 2011;31(10):3423-3428.
175. Yan W, Zhang W, Sun L, et al. Identification of MMP-9 specific microRNA expression profile as potential targets of anti-invasion therapy in glioblastoma multiforme. Brain Res. 2011;1411:108-115.

176. Xia Z, Liu W, Li S, et al. Expression of matrix metalloproteinase-9, type IV collagen and vascular endothelial growth factor in adamantinous craniopharyngioma. Neurochem Res. 2011;36(12):2346-2351.

177. Feng S, Cen J, Huang Y, et al. Matrix metalloproteinase- 2 and -9 secreted by leukemic cells increase the permeability of blood-brain barrier by disrupting tight junction proteins. PLoS One. 2011;6(8): e20599.

178. Parsons SL, Watson SA, Collins HM, Griffin NR, Clarke PA, Steele RJ. Gelatinase (MMP-2 and -9) expression in gastrointestinal malignancy. Br J Cancer. 1998;78(11):1495-1502.

179. Altaş M, Bayrak OF, Ayan E, et al. The effect of polymorphisms in the promoter region of the MMP-1 gene on the occurrence and invasiveness of hypophyseal adenoma. Acta Neurochir (Wien). 2010;152(9): 1611-1617.

180. Tee YT, Liu YF, Chang JT, et al. Single-nucleotide polymorphisms and haplotypes of membrane type 1-matrix metalloproteinase in susceptibility and clinical significance of squamous cell neoplasia of uterine cervix in Taiwan women. Reprod Sci. 2012;19(9): 932-938.

181. Srivastava P, Lone TA, Kapoor R, Mittal RD. Association of promoter polymorphisms in MMP2 and TIMP2 with prostate cancer susceptibility in North India. Arch Med Res. 2012;43(2):117-124.

182. Zhao X, Wang X, Wu W, et al. Matrix metalloproteinase-2 polymorphisms and clinical outcome of Chinese patients with nonsmall cell lung cancer treated with first-line, platinum-based chemotherapy. Cancer. 2012;118(14):3587-3598.

183. Dziki L, Przybyłowska K, Majsterek I, Trzciński R, Mik M, Sygut A. A/G polymorphism of the MMP-7 gene promoter region in colorectal cancer. Pol Przegl Chir. 2011;83(11):622-626.

184. Chaudhary AK, Pandya S, Mehrotra R, Singh M, Singh M. Role of functional polymorphism of matrix metalloproteinase-2 (-1306 C/T and $-168 \mathrm{G} / \mathrm{T})$ and MMP-9 $(-1562 \mathrm{C} / \mathrm{T})$ promoter in oral submucous fibrosis and head and neck squamous cell carcinoma in an Indian population. Biomarkers. 2011;16(7):577-586.

185. Wieczorek E, Reszka E, Gromadzinska J, Wasowicz W. Genetic polymorphism of matrix metalloproteinases in breast cancer. Neoplasma. 2012;59(3):237-247.

186. Zhang LY, Ren KW. Meta-analysis of MMP2 -1306T allele as a protective factor in digestive cancer. Arch Med Res. 2011;42(3): 239-243.

187. Zhang LF, Mi YY, Cao Q, et al. Update analysis of studies on the MMP-9 -1562 C > T polymorphism and cancer risk. Mol Biol Rep. 2012;39(4):3435-3441.

188. Liu D, Guo H, Li Y, Xu X, Yang K, Bai Y. Association between polymorphisms in the promoter regions of matrix metalloproteinases (MMPs) and risk of cancer metastasis: a meta-analysis. PLoS One. 2012;7(2):e31251.

189. Liu D, Duan W, Guo H, Xu X, Bai Y. Meta-analysis of associations between polymorphisms in the promoter regions of matrix metalloproteinases and the risk of colorectal cancer. Int J Colorectal Dis. 2011;26(9):1099-1105.

190. Annabi B, Lachambre MP, Plouffe K, Moumdjian R, Béliveau R. Propranolol adrenergic blockade inhibits human brain endothelial cells tubulogenesis and matrix metalloproteinase-9 secretion. Pharmacol Res. 2009;60(5):438-445.

191. Lirussi F, O'Brien M, Wendremaire M, et al. SAR150640, a selective beta3-adrenoceptor agonist, prevents human myometrial remodelling and activation of matrix metalloproteinase in an in vitro model of chorioamnionitis. Br J Pharmacol. 2010;159(6):1354-1366.

192. Guo K, Ma Q, Wang L, et al. Norepinephrine-induced invasion by pancreatic cancer cells is inhibited by propranolol. Oncol Rep. 2009; 22(4):825-830.

193. Hipskind RA, Bilbe G. MAP kinase signaling cascades and gene expression in osteoblasts. Front Biosci. 1998;3:d804-d816. 
194. Wang SN, Lee KT, Tsai CJ, Chen YJ, Yeh YT. Phosphorylated p38 and JNK MAPK proteins in hepatocellular carcinoma. Eur J Clin Invest. 2012. 2012;42(12):1295-1301.

195. Bang YJ, Kwon JH, Kang SH, Kim JW, Yang YC. Increased MAPK activity and MKP-1 overexpression in human gastric adenocarcinoma. Biochem Biophys Res Commun. 1998;250(1):43-47.

196. Hori M, Inagawa S, Shimazaki J, Itabashi M, Hori M. Overexpression of mitogen-activated protein kinase superfamily proteins unrelated to Ras and AF-1 of estrogen receptor alpha mutation in advanced stage human breast cancer. Pathol Res Pract. 2000;196(12):817-826.

197. Sullivan RJ, Flaherty K. MAP kinase signaling and inhibition in melanoma. Oncogene. 2012. Epub September 3.

198. Al-Azayzih A, Gao F, Goc A, Somanath PR. TGF $\beta 1$ induces apoptosis in invasive prostate cancer and bladder cancer cells via Akt-independent, p38 MAPK and JNK/SAPK-mediated activation of caspases. Biochem Biophys Res Commun. 2012;427(1):165-170.

199. Slattery ML, Lundgreen A, Wolff RK. MAPKinase genes and colon and rectal cancer. Carcinogenesis. 2012;33(12):2398-2408.

200. Gröschl B, Bettstetter M, Giedl C, et al. Expression of the MAP kinase phosphatase DUSP4 is associated with microsatellite instability in colorectal cancer (CRC) and causes increased cell proliferation. Int $J$ Cancer. Epub September 11, 2012.

201. Huang XY, Wang HC, Yuan Z, Huang J, Zheng Q. Norepinephrine stimulates pancreatic cancer cell proliferation, migration and invasion via $\beta$-adrenergic receptor-dependent activation of P38/MAPK pathway. Hepatogastroenterology. 2012;59(115):889-893.

202. Chim H, Armijo BS, Miller E, Gliniak C, Serret MA, Gosain AK. Propranolol induces regression of hemangioma cells through HIF-1 $\alpha$ mediated inhibition of VEGF-A. Ann Surg. 2012;256(1):146-156.

203. Jabbour HN, Milne SA, Williams AR, Anderson RA, Boddy SC. Expression of COX-2 and PGE synthase and synthesis of PGE(2)in endometrial adenocarcinoma: a possible autocrine/paracrine regulation of neoplastic cell function via EP2/EP4 receptors. Br J Cancer. 2001; 85(7):1023-1031.

204. Kundu N, Yang Q, Dorsey R, Fulton AM. Increased cyclooxygenase-2 (cox-2) expression and activity in a murine model of metastatic breast cancer. Int J Cancer. 2001;93(5):681-686.

205. Gatalica Z, Lilleberg SL, Koul MS, et al. COX-2 gene polymorphisms and protein expression in renomedullary interstitial cell tumors. Hum Pathol. 2008;39(10):1495-1504.

206. Okawa T, Yoshinaga K, Uetake H, et al. Cyclooxygenase-2 overexpression is related to polypoid growth and K-ras gene mutation in T1 colorectal carcinomas. Dis Colon Rectum. 2004;47(11):1915-1921.

207. Leung WK, To KF, Ng YP, et al. Association between cyclooxygenase-2 overexpression and missense p53 mutations in gastric cancer. Br J Cancer. 2001;84(3):335-339.

208. Sales KJ, KatzAA, Davis M, et al. Cyclooxygenase-2 expression and prostaglandin $\mathrm{E}(2)$ synthesis are up-regulated in carcinomas of the cervix: a possible autocrine/paracrine regulation of neoplastic cell function via EP2/EP4 receptors. J Clin Endocrinol Metab. 2001;86(5):2243-2249.

209. Brosens LA, Iacobuzio-Donahue CA, Keller JJ, et al. Increased cyclooxygenase-2 expression in duodenal compared with colonic tissues in familial adenomatous polyposis and relationship to the $-765 \mathrm{G}->\mathrm{C}$ COX-2 polymorphism. Clin Cancer Res. 2005;11(11):4090-4096.

210. Markosyan N, Chen EP, Ndong VN, et al. Deletion of cyclooxygenase 2 in mouse mammary epithelial cells delays breast cancer onset through augmentation of type 1 immune responses in tumors. Carcinogenesis. 2011;32(10):1441-1449.

211. Santander S, Cebrián C, Esquivias P, et al. Cyclooxygenase inhibitors decrease the growth and induce regression of human esophageal adenocarcinoma xenografts in nude mice. Int J Oncol. 2012;40(2): 527-534.

212. Rozic JG, Chakraborty C, Lala PK. Cyclooxygenase inhibitors retard murine mammary tumor progression by reducing tumor cell migration, invasiveness and angiogenesis. Int J Cancer. 2001;93(4):497-506.

213. Kang S, Kim YB, Kim MH, et al. Polymorphism in the nuclear factor kappa-B binding promoter region of cyclooxygenase-2 is associated with an increased risk of bladder cancer. Cancer Lett. 2005; 217(1):11-16.
214. Sakoda LC, Gao YT, Chen BE, et al. Prostaglandin-endoperoxide synthase 2 (PTGS2) gene polymorphisms and risk of biliary tract cancer and gallstones: a population-based study in Shanghai, China. Carcinogenesis. 2006;27(6):1251-1256.

215. Park JM, Choi JE, Chae MH, et al. Relationship between cyclooxygenase $8473 \mathrm{~T}>\mathrm{C}$ polymorphism and the risk of lung cancer: a casecontrol study. BMC Cancer. 2006;6:70.

216. Lira MG, Mazzola S, Tessari G, et al. Association of functional gene variants in the regulatory regions of COX-2 gene (PTGS2) with nonmelanoma skin cancer after organ transplantation. Br J Dermatol. 2007;157(1):49-57.

217. Upadhyay R, Jain M, Kumar S, Ghoshal UC, Mittal B. Functional polymorphisms of cyclooxygenase-2 (COX-2) gene and risk for esophageal squmaous cell carcinoma. Mutat Res. 2009;663(1-2): 52-59.

218. Ben Nasr H, Chahed K, Bouaouina N, Chouchane L. PTGS2 (COX-2) $-765 \mathrm{G}>\mathrm{C}$ functional promoter polymorphism and its association with risk and lymph node metastasis in nasopharyngeal carcinoma. Mol Biol Rep. 2009;36(1):193-200.

219. Zhao D, Xu D, Zhang X, et al. Interaction of cyclooxygenase-2 variants and smoking in pancreatic cancer: a possible role of nucleophosmin. Gastroenterology. 2009;136(5):1659-1668.

220. Lurie G, Terry KL, Wilkens LR, et al. Pooled analysis of the association of PTGS2 rs5275 polymorphism and NSAID use with invasive ovarian carcinoma risk. Cancer Causes Control. 2010;21(10):1731-1741.

221. Abraham JE, Harrington P, Driver KE, et al. Common polymorphisms in the prostaglandin pathway genes and their association with breast cancer susceptibility and survival. Clin Cancer Res. 2009;15(6): 2181-2191.

222. Li Y, He W, Liu T, Zhang Q. A new cyclo-oxygenase-2 gene variant in the Han Chinese population is associated with an increased risk of gastric carcinoma. Mol Diagn Ther. 2010;14(6):351-355.

223. Zheng J, Chen S, Jiang L, You Y, Wu D, Zhou Y. Functional genetic variations of cyclooxygenase-2 and susceptibility to acute myeloid leukemia in a Chinese population. Eur J Haematol. 2011;87(6): 486-493.

224. Amirian ES, Ittmann MM, Scheurer ME. Associations between arachidonic acid metabolism gene polymorphisms and prostate cancer risk. Prostate. 2011;71(13):1382-1389.

225. Peters WH, Lacko M, Te Morsche RH, Voogd AC, Oude Ophuis MB, Manni JJ. COX-2 polymorphisms and the risk for head and neck cancer in white patients. Head Neck. 2009;31(7):938-943.

226. Gong Z, Bostick RM, Xie D, et al. Genetic polymorphisms in the cyclooxygenase-1 and cyclooxygenase-2 genes and risk of colorectal adenoma. Int J Colorectal Dis. 2009;24(6):647-654.

227. Akkız H, Bayram S, Bekar A, Akgöllü E, Ülger Y. Functional polymorphisms of cyclooxygenase-2 gene and risk for hepatocellular carcinoma. Mol Cell Biochem. 2011;347(1-2):201-208.

228. Dong J, Dai J, Zhang M, Hu Z, Shen H. Potentially functional COX$2-1195 \mathrm{G}>\mathrm{A}$ polymorphism increases the risk of digestive system cancers: a meta-analysis. J Gastroenterol Hepatol. 2010;25(6): 1042-1050.

229. Zhu W, Wei BB, Shan X, Liu P. $-765 \mathrm{G}>\mathrm{C}$ and $8473 \mathrm{~T}>\mathrm{C}$ polymorphisms of COX-2 and cancer risk: a meta-analysis based on 33 case-control studies. Mol Biol Rep. 2010;37(1):277-288.

230. Shrubsole MJ, Cai Q, Wen W, et al. Urinary prostaglandin E2 metabolite and risk for colorectal adenoma. Cancer Prev Res (Phila). 2012; 5(2):336-342.

231. Hogendorf P, Durczyński A, Kumor A, Strzelczyk J. Prostaglandin E2 (PGE2) in portal blood in patients with pancreatic tumor - a single institution series. J Invest Surg. 2012;25(1):8-13.

232. Rasmuson A, Kock A, Fuskevåg OM, et al. Autocrine prostaglandin E2 signaling promotes tumor cell survival and proliferation in childhood neuroblastoma. PLoS One. 2012;7(1):e29331.

233. Han S, Roman J. Suppression of prostaglandin E2 receptor subtype EP2 by PPARgamma ligands inhibits human lung carcinoma cell growth. Biochem Biophys Res Commun. 2004;314(4):1093-1099. 
234. Glasner A, Avraham R, Rosenne E, et al. Improving survival rates in two models of spontaneous postoperative metastasis in mice by combined administration of a beta-adrenergic antagonist and a cyclooxygenase-2 inhibitor. J Immunol. 2010;184(5):2449-2457.

235. Benish M, Bartal I, Goldfarb Y, et al. Perioperative use of beta-blockers and COX-2 inhibitors may improve immune competence and reduce the risk of tumor metastasis. Ann Surg Oncol. 2008;15(7):2042-2052.

236. Gupta SC, Hevia D, Patchva S, Park B, Koh W, Aggarwal BB. Upsides and downsides of reactive oxygen species for cancer: the roles of reactive oxygen species in tumorigenesis, prevention, and therapy. Antioxid Redox Signal. 2012;16(11):1295-1322.

237. Marra M, Sordelli IM, Lombardi A, Lamberti M, Tarantino L, et al Molecular targets and oxidative stress biomarkers in hepatocellular carcinoma: an overview. J Transl Med. 2011;9:171

238. Zhang Q, Ma Y, Cheng YF, Li WJ, Zhang Z, Chen SY. Involvement of reactive oxygen species in 2-methoxyestradiol-induced apoptosis in human neuroblastoma cells. Cancer Lett. 2011;313(2):201-210.

239. Wang HC, Choudhary S. Reactive oxygen species-mediated therapeutic control of bladder cancer. Nat Rev Urol. 2011;8(11):608-616.

240. Rogalska A, Gajek A, Szwed M, Jóźwiak Z, Marczak A. The role of reactive oxygen species in WP 631-induced death of human ovarian cancer cells: a comparison with the effect of doxorubicin. Toxicol in Vitro. 2011;25(8):1712-1720.

241. Gupta-Elera G, Garrett AR, Robison RA, O'Neill KL. The role of oxidative stress in prostate cancer. Eur J Cancer Prev. 2012;21(2): 155-162.

242. Hong CC, Ambrosone CB, Ahn J, et al. Genetic variability in ironrelated oxidative stress pathways (Nrf2, NQ01, NOS3, and HO-1), iron intake, and risk of postmenopausal breast cancer. Cancer Epidemiol Biomarkers Prev. 2007;16(9):1784-1794.

243. Woodson K, Tangrea JA, Lehman TA, et al. Manganese superoxide dismutase (MnSOD) polymorphism, alpha-tocopherol supplementation and prostate cancer risk in the alpha-tocopherol, beta-carotene cancer prevention study (Finland). Cancer Causes Control. 2003;14(6) 513-518.

244. Wang S, Wang F, Shi X, et al. Association between manganese superoxide dismutase (MnSOD) Val-9Ala polymorphism and cancer risk - A meta-analysis. Eur J Cancer. 2009;45(16):2874-2881.

245. Mao C, Qiu LX, Zhan P, et al. MnSOD Val16Ala polymorphism and prostate cancer susceptibility: a meta-analysis involving 8,962 subjects. J Cancer Res Clin Oncol. 2010;136(7):975-979.

246. Ma X, Chen C, Xiong H, et al. No association between SOD2 Val16Ala polymorphism and breast cancer susceptibility: a meta-analysis based on 9,710 cases and 11,041 controls. Breast Cancer Res Treat 2010;122(2):509-514.

247. Larson BE, Stockwell DW, Boas S, Andrews T, Wellman GC, et al. Cardiac reactive oxygen species after traumatic brain injury. $J$ Surg Res. 2012;173(2):e73-81.

248. Ma L, Gul R, Habibi J, et al. Nebivolol improves diastolic dysfunction and myocardial remodeling through reductions in oxidative stress in the transgenic (mRen2) rat. Am J Physiol Heart Circ Physiol. 2012; 302(11):H2341-H2351.

249. Le Pennec S, Mirebeau-Prunier D, Boutet-Bouzamondo N, et al. Nitric oxide and calcium participate in the fine regulation of mitochondrial biogenesis in follicular thyroid carcinoma cells. J Biol Chem. 2011; 286(20):18229-18239.

Cancer Management and Research

\section{Publish your work in this journal}

Cancer Management and Research is an international, peer-reviewed open access journal focusing on cancer research and the optimal use of preventative and integrated treatment interventions to achieve improved outcomes, enhanced survival and quality of life for the cancer patient. The journal welcomes original research, clinical \& epidemiological
250. Bentz BG, Chandra R, Haines GK 3rd, Robinson AM, Shah P, Radosevich JA. Nitric oxide and apoptosis during human head and neck squamous cell carcinoma development. Am J Otolaryngol. 2002;23(1):4-11.

251. Siripin D, Fucharoen S, Tanyong DI. Nitric oxide and caspase 3 mediated cytokine induced apoptosis in acute leukemia. Asian Pac J Allergy Immunol. 2011;29(1):102-111.

252. Saleem W, Suzuki Y, Mobaraki A, Yoshida Y, Noda S, et al. Reduction of nitric oxide level enhances the radiosensitivity of hypoxic non-small cell lung cancer. Cancer Sci. 2011;102(12):2150-2156.

253. Guler E, Baspinar O, Cekmen M, Kilinc M, Balat A. Nitric oxide: a new biomarker of Doxorubicin toxicity in children? Pediatr Hematol Oncol. 2011;28(5):395-402.

254. Chin MP, Deen WM. Prediction of nitric oxide concentrations in melanomas. Nitric Oxide. 2010;23(4):319-326.

255. Ellie E, Loiseau H, Lafond F, Arsaut J, Demotes-Mainard J. Differential expression of inducible nitric oxide synthase mRNA in human brain tumours. Neuroreport. 1995;7(1):294-296.

256. Zhang W, He XJ, Ma YY, et al. Inducible nitric oxide synthase expression correlates with angiogenesis, lymphangiogenesis, and poor prognosis in gastric cancer patients. Hum Pathol. 2011;42(9): 1275-1282.

257. Glynn SA, Boersma BJ, Dorsey TH, et al. Increased NOS2 predicts poor survival in estrogen receptor-negative breast cancer patients J Clin Invest. 2010;120(11):3843-3854.

258. Cardnell RJ, Mikkelsen RB. Nitric oxide synthase inhibition enhances the antitumor effect of radiation in the treatment of squamous carcinoma xenografts. PLoS One. 2011;6(5):e20147.

259. Ryk C, Steineck G, Wiklund NP, Nyberg T, de Verdier PJ. The (CCTTT) $\mathrm{n}$ microsatellite polymorphism in the nitric oxide synthase 2 gene may influence bladder cancer pathogenesis. J Urol. 2010;184(5): 2150-2157.

260. Shen $\mathrm{CH}$, Wang YH, Wang WC, et al. Inducible nitric oxide synthase promoter polymorphism, cigarette smoking, and urothelial carcinoma risk. Urology. 2007;69(5):1001-1006.

261. Kaise M, Miwa J, Suzuki N, et al. Inducible nitric oxide synthase gene promoter polymorphism is associated with increased gastric mRNA expression of inducible nitric oxide synthase and increased risk of gastric carcinoma. Eur J Gastroenterol Hepatol. 2007;19(2) 139-145.

262. Arıkan S, Cacina C, Guler E, Çulcu S, Tuna G, Yaylım-Eraltan I. The effects of NOS3 Glu298Asp variant on colorectal cancer risk and progression in Turkish population. Mol Biol Rep. 2012;39(3): 3245-3249.

263. Han X, Zheng T, Lan Q, et al. Genetic polymorphisms in nitric oxide synthase genes modify the relationship between vegetable and fruit intake and risk of non-Hodgkin lymphoma. Cancer Epidemiol Biomarkers Prev. 2009;18(5):1429-1438.

264. Hao Y, Montiel R, Huang Y. Endothelial nitric oxide synthase (eNOS) $894 \mathrm{G}>\mathrm{T}$ polymorphism is associated with breast cancer risk: a meta-analysis. Breast Cancer Res Treat. 2010;124(3):809-813.

265. Dai Y, Hou F, Buckmiller L, et al. Decreased eNOS protein expression in involuting and propranolol-treated hemangiomas. Arch Otolaryngol Head Neck Surg. 2012;138(2):177-182.

studies, reviews \& evaluations, guidelines, expert opinion \& commentary, case reports \& extended reports. The manuscript management system is completely online and includes a very quick and fair peerreview system, which is all easy to use. Visit http://www.dovepress.com/ testimonials.php to read real quotes from published authors. 